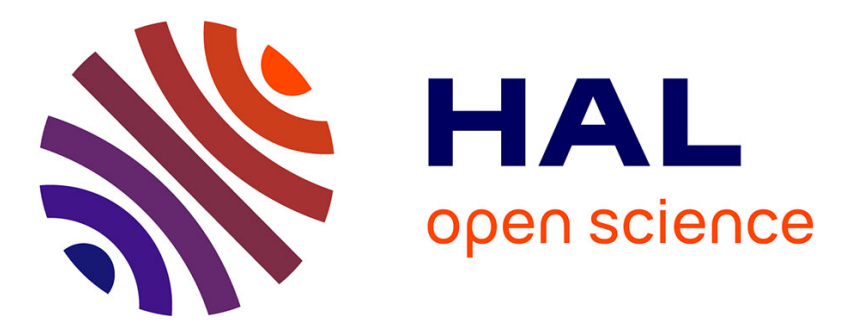

\title{
Geological, geochronological and geochemical features of granulites in the Eastern Tianshan, NW China
}

Liangshu S. Shu, Jinhai Yu, Jacques Charvet, Sébastien Laurent-Charvet, Haiqing Sang, Rengu Zhang

\section{- To cite this version:}

Liangshu S. Shu, Jinhai Yu, Jacques Charvet, Sébastien Laurent-Charvet, Haiqing Sang, et al.. Geological, geochronological and geochemical features of granulites in the Eastern Tianshan, NW China. Journal of Southeast Asian earth sciences, 2004, 24, pp.25-41. 10.1016/j.jseaes.2003.07.002 . hal00089676

\section{HAL Id: hal-00089676 \\ https://hal-insu.archives-ouvertes.fr/hal-00089676}

Submitted on 15 Sep 2006

HAL is a multi-disciplinary open access archive for the deposit and dissemination of scientific research documents, whether they are published or not. The documents may come from teaching and research institutions in France or abroad, or from public or private research centers.
L'archive ouverte pluridisciplinaire HAL, est destinée au dépôt et à la diffusion de documents scientifiques de niveau recherche, publiés ou non, émanant des établissements d'enseignement et de recherche français ou étrangers, des laboratoires publics ou privés. 


\title{
Geological, geochronological and geochemical features of granulites in the Eastern Tianshan, NW China
}

\author{
Liangshu Shu ${ }^{a}$, Jinhai Yu ${ }^{a}$, J. Charvet ${ }^{b}$, S. Laurent-Charvet ${ }^{b}$, Haiqing Sang ${ }^{c}$ and Rengu \\ Zhang $^{c}$ \\ ${ }^{a}$ Department of Earth Sciences, State Key Laboratory of Metallization, Nanjing University, \\ 210093, Nanjing, China \\ ${ }^{\mathrm{b}}$ Institut des Sciences de la Terre, Université d'Orléans, 45067, Orleans, France \\ ${ }^{\mathrm{c}}$ Institute of Geology and Geophysics, Chinese Academy of Sciences, 100087, Beijing, China
}

\section{Abstract}

This paper reports new results on the petrology, geochronology and geochemistry of two kmscale high-pressure granulite exposures, namely the Weiya and the Yushugou granulites, that occur in the central and southern Tianshan Paleozoic sub-belts, respectively. Petrological and geochemical results suggest that the Weiya and the Yushugou granulites are different in both the rock types and geological structures. The protolith of the Weiya granulite is basic to intermediate rocks, and that of the Yushugou granulite is basic rocks; the former is distributed as fault-bounded blocks within the Precambrian schist-gneiss, and the latter occurs as thrust slabs in the allochthonous ophiolitic mélange. Observation of deformation structures provides some evidence for two-phase ductile deformation of the Tianshan granulites, characterized by deformed garnet-pyroxene and deformed feldspar-quartz microstructures, corresponding to rheological conditions of the lower crustal level and of the middle crustal level, respectively. The deformation structures also indicate that the Weiya granulite was involved in the late stage retrograde metamorphism forming new amphibole, following a thrusting movement toward the north and ductile deformation of feldspar-quartz grains. The Yushugou granulite underwent strong ductile shearing during the Silurian-Devonian interval. Three stages of metamorphism are recorded by mineral assemblages of the Weiya granulite: $\mathrm{M}_{1}=\mathrm{Pl}+\mathrm{Qtz}+\mathrm{Bt}$, $\mathrm{M}_{2}=\mathrm{Cpx}+\mathrm{Grt}+\mathrm{Pl}+\mathrm{Qtz}+\mathrm{Atp} \pm \mathrm{Opx}$, and $\mathrm{M}_{3}=\mathrm{Amp}+\mathrm{Ep}+\mathrm{Pl}+\mathrm{Bt}+\mathrm{Qtz}$, in contrast to a two-stage metamorphic history of the Yushugou granulite: $\mathrm{M}_{1}=\mathrm{Cpx}+\mathrm{Grt}+\mathrm{Pl} \pm \mathrm{Hyp}$, $\mathrm{M}_{2}=\mathrm{Amp}+\mathrm{Pl}+\mathrm{Qtz} \pm \mathrm{Bt}$. The $P-T$ condition estimates suggest that the Weiya granulite was formed between $910-1025{ }^{\circ} \mathrm{C}$ and $1.08-1.12 \mathrm{GPa}$, and underwent retrograde metamorphism at $650-670{ }^{\circ} \mathrm{C}$, while the peak metamorphism of the Yushugou granulite took place between 800-870 ${ }^{\circ} \mathrm{C}$ and $0.88-1.13 \mathrm{GPa}$. Geochemical characteristics (major, REE and incompatible elements) of the Weiya and Yushugou granulites indicate that their protoliths were formed in a volcanic arc setting, implying that a late Precambrian active continental margin may have existed in the study area. The Sm-Nd isochron dating for the Weiya granulite suggests that the peak metamorphism occurred at $538 \pm 24 \mathrm{Ma}$, which was likely related to the ancient plate subduction. The ${ }^{40} \mathrm{Ar} /{ }^{39} \mathrm{Ar}$ dating on amphibole grains separated from the Weiya granulite yielded a plateau age of $432 \pm 1 \mathrm{Ma}$ for the retrograde metamorphism, which represents an exhumation age, suggesting a significant early Paleozoic tectonothermal event.

Author Keywords: Petrology; Isotopic dating; Geochemistry; Granulite; Exhumation; Tianshan belt; NW China 


\section{Introduction}

In the central Asia, the roughly E-W-trending Tianshan is a $\sim 400 \mathrm{~km}$-wide orogenic belt formed by the collision between the Siberian and the Tarim blocks during the Late Paleozoic (Coleman, 1989; Sengor et al., 1993; Allen et al., 1993a; Allen et al., 1993b; Carroll et al., 1995; Burtman, 1975; Ren and Chen, 1989; Xiao et al., 1990; He et al., 1994 and LaurentCharvet et al., 2002). The Chinese Tianshan, which is composed of three sub-belts (i.e. the southern, central and northern Tianshan sub-belts), has been interpreted as the locus of polyphase accretion-collision ( Allen et al., 1993a; Xiao et al., 1990; Ma et al., 1993; Ma et al., 1997; Xu, 1995; Shu et al., 1999 and Wartes et al., 2002). The Paleozoic tectonic framework seems to be a complex collage ( Coleman, 1989; Sengor et al., 1993 and Shu et al., 2000), which is composed of volcanic islands and continental blocks. Polyphase deformation affected large areas of Central Asia ( Allen et al., 1995 and Allen et al., 2001). Some deepseated metamorphic slabs were exhumated to shallow crustal levels along suture zones, e.g. the blueschist slab at Kumux in the northern margin of the southern Tianshan ( Gao et al., 1995), the eclogite blocks in the Hark Mountains of the southwestern Tianshan (Gao et al., 1997 and Gao et al., 1999), and the granulitic blocks in the northern margin of the southern Tianshan ( Shu et al., 1996 and Wang et al., 1999).

Granulite is an indicator of high-grade metamorphism and deep-seated ductile deformation (Bohlen and Mezger, 1989 and Liu, 1997). Its geochemical characteristics can be used as fingerprints of lower crustal rock units ( Yu et al., 2003). Exposure of granulite results from exhumation events ( Menzies, 1992), following retrograde metamorphism due to decompression and cooling ( Ellis, 1987 and Liu et al., 2000). Therefore, granulite is an important candidate for the study of metamorphic and exhumation processes.

Two major exposures of granulites are distributed at Weiya and Yushugou in the northern boundaries of the central Tianshan and of the southern Tianshan sub-belts, respectively (Fig. 1, Fig. 2 and Fig. 3). The geometric features of the Yushugou and the Weiya granulite blocks have been described by Shu et al. (1996). However, petrological, geochemical features and tectonic settings of the two granulites are poorly known. This paper presents new results on the Weiya and the Yushugou granulites, including their mineral assemblages, geochemical features, ductile deformation features and radiogenic age data. These data, together with other geological observations, allow us to propose that a major tectonothermal event occurred in the Tianshan belt during the early Paleozoic. 


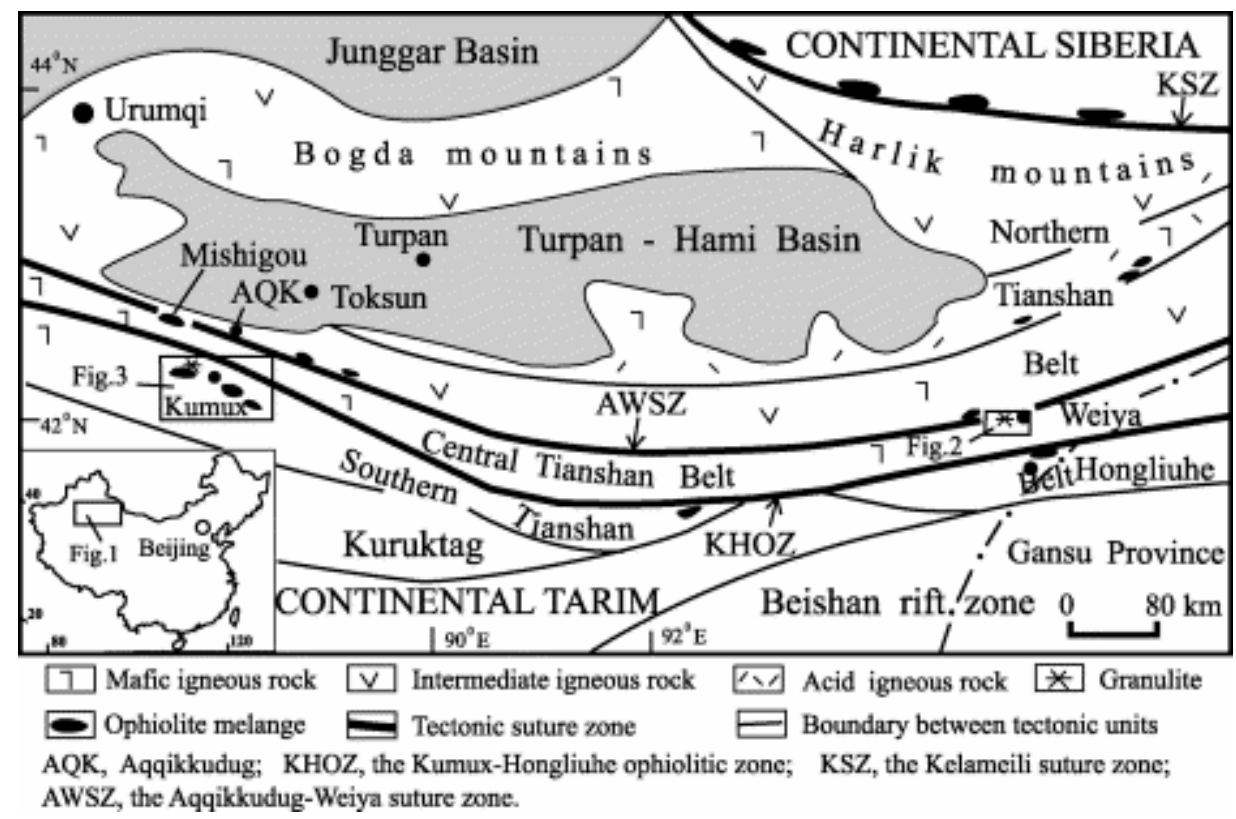

Fig. 1. A sketch map showing the tectonic units of the eastern Tianshan, NW China (modified from XBGMR: Xinjiang Bureau of Geology and Mineral Resources, 1992; Shu et al., 1999 and Shu et al., 2002).

\section{Geological background}

The sub-E-W-trending Chinese Tianshan belt extends for more than $1500 \mathrm{~km}$ in the Xinjiang Uygur Autonomous Region. Relics of high-pressure metamorphic minerals, such as glaucophane and phengite, in the Aqsu region imply that the northern margin of the Tarim microcontinent was involved in a HP/LT subduction metamorphism as early as the NeoProterozoic, dated at $\sim 700 \mathrm{Ma}(718 \pm 22$ and $710 \pm 21$ Ma by K-Ar method on glaucophane grains, $698 \pm 26$ and $714 \pm 24 \mathrm{Ma}$ by $\mathrm{Rb}-\mathrm{Sr}$ method on phengitic mica and whole rock, Nakajima et al., 1990). At least two Paleozoic sutures across the Tianshan Range have been identified ( Windley et al., 1990; Allen et al., 1993a and Allen et al., 1993b), a southern suture between the Tarim microcontinent and the Tianshan Range, and a northern suture between the central Tianshan active continental margin and the northern Tianshan Carboniferous island arc. 


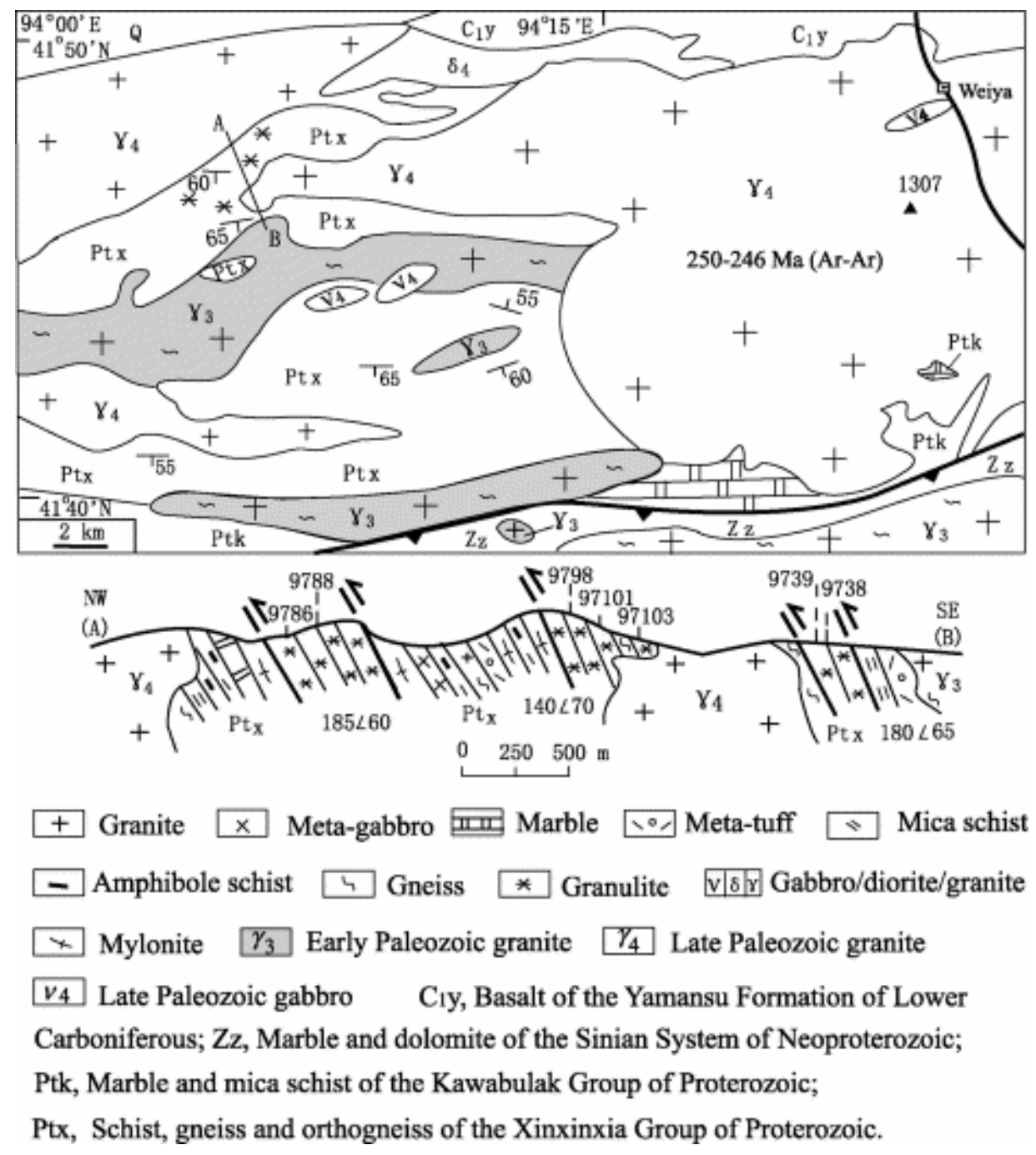

Fig. 2. Simplified geological map (upper) and structural section (lower) for the Weiya granulite (modified from 1:1500000 Xinjiang geological map, XBGRM, 1992). 


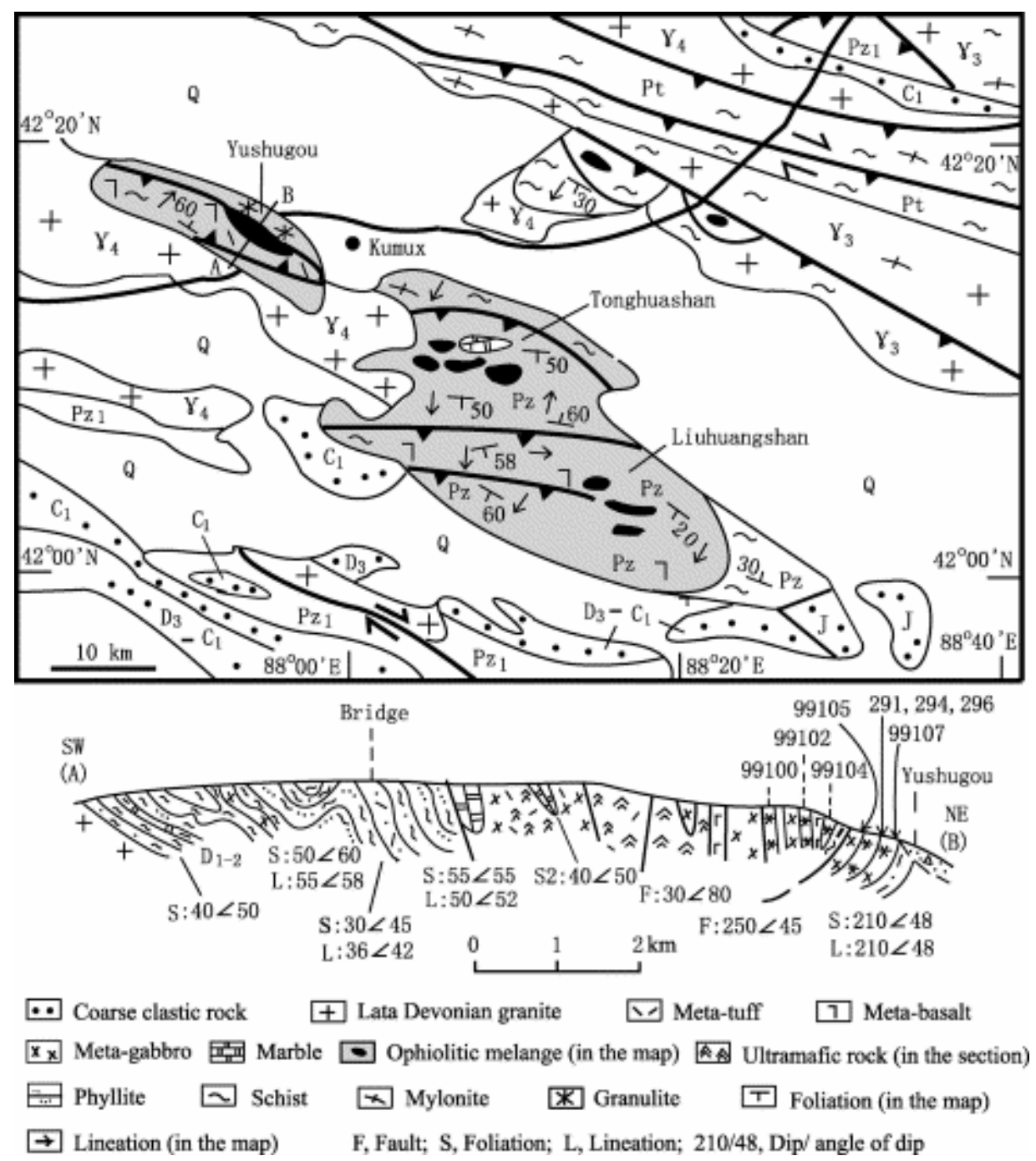

Fig. 3. Simplified geological map (upper) and structural section (lower) for the Yushugou granulite (modified from 1:1000000 Xinjiang geological map, XBGRM, 1992)

The sub-E-W-trending Aqqikkudug-Weiya suture zone (AWSZ in Fig. 1) separates the northern Tianshan sub-belt to the north from the central Tianshan sub-belt to the south; and the sub-E-W-trending Kumux-Hongliuhe ophiolitic zone (KHOZ in Fig. 1) separates the central Tianshan sub-belt from the southern Tianshan sub-belt. The AWSZ is a Paleozoic suture zone ( Ma et al., 1993; Gu et al., 1999 and Guo et al., 2002) and consists of Ordovician-Silurian meta-turbidite and ophiolitic melange ( Guo et al., 1999 and Gu et al., 1999), containing HP-type phengite schist and glaucophane schist exposed at Gangou ( Allen et al., 1993a), Mishigou and Weiya ( Che et al., 1994 and Shu et al., 1999). The KHOZ is an ophiolitic zone, composed of Silurian-Devonian turbidite, pillow basalt, red chert and maficultramafic rocks ( XBGMR: Xinjiang Bureau of Geology and Mineral Resources, 1993; Shu et al., 1996; Shu et al., 1997; Shu et al., 2002 and Guo et al., 2002). The central Tianshan volcanic arc is composed of the Ordovician calc-alkaline basalt, andesite, pyroclastic rocks, greywacke and the Silurian meta-flysch (Guo et al., 2002). This arc developed upon the central Tianshan Precambrian metamorphic basement. The Weiya granulite is distributed in the Weiya area along the AWSZ and the Yushugou granulite is exposed around Yushugou along the KHOZ ( Fig. 2 and Fig. 3). 


\section{Geology of granulites}

\subsection{Weiya granulite}

\subsubsection{Geological features}

The Weiya granulite is composed of several NE-NEE-striking granulite slabs, each about 20 $40 \mathrm{~m}$ wide and 2-3 km long (Fig. 2). These granulite slabs were displaced into metamorphic rocks of the Proterozoic basement that consist of amphibolite, gneiss, gneissic granodiorite, meta-gabbro, mica-schist and marble. Both the granulite and the basement metamorphic rocks were locally intruded by late Palaeozoic granite dated at $250 \pm 8$ and $246 \pm 6 \mathrm{Ma}$ by ${ }^{40} \mathrm{Ar} /{ }^{39} \mathrm{Ar}$ on biotite minerals from the central part of the Weiya granite (Hu and Zhang, 1995).

There are two kinds of granulite: basic and intermediate. Four types of structures are well developed: massive (fine-grained), banded, porphyroblastic and brecciated. Some residual basic enclaves, with a size from 2 to $5 \mathrm{~cm}$, are distributed in fine-grained granulite. Granulite and surrounding Proterozoic metamorphic rocks underwent intensive ductile deformation characterized by microstructures of feldspar-quartz grains (Samples 9738, 9739, 9786, 9788 in Table 1), and developed identical mylonitic foliation and stretching lineation.

Table 1. Petrographical features of granulites in the eastern Tianshan, Xinjiang, northwestern China

\begin{tabular}{|c|c|c|c|c|c|c|c|c|}
\hline \multirow{2}{*}{$\begin{array}{l}\text { Location } \\
\text { Sample No. }\end{array}$} & \multicolumn{8}{|c|}{ Weiya granulites (geological section of Fig. 2) } \\
\hline & 9738 & 9739 & 9798 & 99100 & 97101 & 97103 & 9786 & 9788 \\
\hline Texture & \multicolumn{2}{|l|}{ Porphyroblastic } & \multicolumn{2}{|l|}{ Poxphyroblastic } & \multicolumn{2}{|l|}{ Porphyroblastic } & $\begin{array}{l}\text { Fine granulss } \\
(0.1-0.3 \mathrm{~mm})\end{array}$ & \\
\hline & Banded & Bsanded & Bsanded & Bended & Banded & Banded & Massive & \\
\hline \multirow[t]{4}{*}{ Porphyroblast } & cpx $(20 \%)$ & cpx (15\%) & $\operatorname{cpx}(15 \%)$ & $\operatorname{cpx}(15 \%)$ & $\operatorname{cpx}(15-20 \%)$ & epx (15\%) & epx $(40-45 \%)$ & cpx $(40-45 \%)$ \\
\hline & $\operatorname{grt}(10 \% 6)$ & $\operatorname{grt}(5-10 \%)$ & $\operatorname{grt}(12 \%)$ & $\operatorname{gt}(10 \%)$ & $\operatorname{grt}(5-10 \%)$ & $\operatorname{grt}(5-10 \%)$ & grt (20\%) & $\operatorname{grt}(20-25 \%)$ \\
\hline & $\operatorname{amp}(2-3 \%)$ & \multirow[t]{2}{*}{$\operatorname{amp}(3-5 \%)$} & $\operatorname{amp}(3-5 \%)$ & $\sin (2-3 \%)$ & $\operatorname{armp}(5 \%)$ & $\operatorname{smp}(5 \%)$ & $\mathrm{pl}(20 \%)$ & $\mathrm{pl}(15-20 \%)$ \\
\hline & opx $(1-3 \%)$ & & opx $(5-8 \%)$ & $\begin{array}{l}\text { opx }(1-3 \%) \\
\text { pl (5\%) }\end{array}$ & $\begin{array}{l}\text { opx }(5-8 \%) \\
\text { atp (1\%) }\end{array}$ & opx $(5-8 \%)$ & $\begin{array}{l}\mathrm{qtz}(3-5 \%) \\
\text { bt }(1-2 \%)\end{array}$ & $\begin{array}{l}\text { qtz }(3 \%) \\
\text { bt }(3-4 \%)\end{array}$ \\
\hline Groundmass & $\mathrm{pl}+\mathrm{grt}+\mathrm{pyr}+\mathrm{qtz}^{\mathrm{t}}+\mathrm{ms}$ & $P l+g r t+p y r+q t z$ & $\begin{array}{l}\mathrm{pl}+\mathrm{gt}+\mathrm{pyr}+q \mathrm{qz}+ \\
\mathrm{crd}+\mathrm{ep}+\mathrm{ms}+\mathrm{bt}\end{array}$ & $\begin{array}{l}\mathrm{pl}+\mathrm{grt}+ \\
\mathrm{pyr}+\mathrm{qtz}\end{array}$ & $\begin{array}{l}\mathrm{pl}+\mathrm{g} z \mathrm{t}+\mathrm{pyr}+ \\
\mathrm{qtz} \text { wo }(1-2 \%)\end{array}$ & $\begin{array}{l}\mathrm{pl}+\mathrm{grt}+\mathrm{pyr} \\
+\mathrm{qtz} \mathrm{crd} \\
(1-2 \%)+ \\
\text { ep }(1-2 \%)\end{array}$ & samp $(5-10 \%)$ & $\operatorname{sanp}(8 \%)$ \\
\hline $\begin{array}{l}\text { Inclusion } \\
\text { Accessory } \\
\text { minerals }\end{array}$ & $\begin{array}{l}(1-3 \%): q t z+b t+p l \\
\operatorname{mag}(1 \%): s p l \text { (rase) }\end{array}$ & $\begin{array}{l}(2-3 \%): \mathrm{bx}+\mathrm{pl} \\
\mathrm{mag}(2 \%), \mathrm{spl}+\mathrm{ap} \text { (rase) }\end{array}$ & $\begin{array}{l}(1-2 \%): \mathrm{bt}+\mathrm{pl} \\
\mathrm{mag}+\mathrm{ilm}(1 \%)\end{array}$ & $\begin{array}{r}\operatorname{mag}(1 \%) \text {, spl } \\
+ \text { sph (rase) }\end{array}$ & $\operatorname{mag}(1 \%): \operatorname{sp}(r a s e)$ & $\operatorname{mag}+i \operatorname{lm}(1 \%)$ & $\begin{array}{l}\operatorname{mag}(2 \%), \mathrm{spl} \\
+ \text { ap (rare) }\end{array}$ & $\begin{array}{l}\text { mag (1\%): } \\
\text { spl (rase) }\end{array}$ \\
\hline Lithology & Climpyroxene granulite & $\begin{array}{l}\text { Clinopyroxene } \\
\text { granulite }\end{array}$ & $\begin{array}{l}\text { Two-pyroxene } \\
\text { gramlite }\end{array}$ & $\begin{array}{l}\text { Clinopyroxene } \\
\text { granlite }\end{array}$ & $\begin{array}{l}\text { Two-pyroxene } \\
\text { granulite }\end{array}$ & $\begin{array}{l}\text { Two-pyrowene } \\
\text { granalite }\end{array}$ & $\begin{array}{l}\text { Clinopyroxene } \\
\text { granulite }\end{array}$ & $\begin{array}{l}\text { Clinopyroxene } \\
\text { granulite }\end{array}$ \\
\hline Location & \multicolumn{8}{|c|}{ Yuduguo gramlies (gedogical section of Fig. 3) } \\
\hline Sample No. & 99102 & 99104 & 99107 & 294 & 296 & 99106 & 291 & 99105 \\
\hline Texture & Porphyrobsastic & & Poxphyroblastic & & & $\begin{array}{l}\text { Fine granular } \\
(0.2-0.5 \mathrm{~mm})\end{array}$ & & \\
\hline \multirow{7}{*}{$\begin{array}{l}\text { Structure } \\
\text { Porphyroblast }\end{array}$} & & Bsanded & Bsanded & Bended & Bsanded & Massive & Massive & Massive \\
\hline & epx $(15-20 \%)$ & epx (15\%) & cpx (15\%) & $\operatorname{cpx}(15-20 \%)$ & $\operatorname{cpx}(20 \%)$ & $\operatorname{cpx}(55 \%)$ & $\operatorname{cpx}(40 \%)$ & cpx $(45 \%)$ \\
\hline & $\operatorname{grt}(5-10 \%)$ & $\operatorname{gnt}(5-10 \%)$ & $\operatorname{grt}(5-10 \%)$ & $\operatorname{gt}(5-10 \%)$ & $\operatorname{grt}(5-10 \%)$ & gnt $(20 \%)$ & gnt $(15-20 \%)$ & grt $(20 \%)$ \\
\hline & $\operatorname{amp}(2-3 \%)$ & $\operatorname{amp}(2-3 \%)$ & $\operatorname{amp}(2-3 \%)$ & $\operatorname{smp}(5 \%)$ & $\operatorname{smp}(2-3 \%)$ & $\operatorname{smp}(8-10 \%)$ & $\operatorname{smp}(5-8 \%)$ & $\operatorname{amp}(5-8 \%)$ \\
\hline & \multirow[t]{3}{*}{$\mathrm{pl}(6-7 \%)$} & \multirow{3}{*}{$\begin{array}{l}\text { Pl }(5-8 \%) \\
q \text { tz }(2-3 \%)\end{array}$} & \multirow{3}{*}{$\begin{array}{l}\mathrm{pl}(5-9 \%) \\
\mathrm{qtz}(1-3 \%)\end{array}$} & $\cos (5-8 \%)$ & \multirow{3}{*}{$\begin{array}{l}\text { opx }(1-3 \%) \\
\text { pl }(3-5 \%)\end{array}$} & $\mathrm{pl}(15 \%)$ & $\mathrm{pl}(13-18 \%)$ & opx $(2-3 \%)$ \\
\hline & & & & ab $(1-3 \%)$ & & $\mathrm{qtz}(3 \%)$ & $\mathrm{qtz}(3-5 \%)$ & $\mathrm{pl}(20 \%)$ \\
\hline & & & & $\operatorname{stp}(1-3 \%)$ & & bt $(2-3 \%)$ & bt $(2-3 \%)$ & $\mathrm{qtz}(3 \%)$ \\
\hline Groundmess & $\mathrm{pl}+\mathrm{grt}+\mathrm{pyr}+\mathrm{qtz}^{\mathrm{tz}}$ & $\mathrm{Pl}+\mathrm{grt}+\mathrm{cpxht}+q \mathrm{qz}$ & $p l+g t+p y r+q q z$ & $\begin{array}{l}\mathrm{pl}+\mathrm{grt}+ \\
\text { cpscpx }+\mathrm{qtz}\end{array}$ & $\begin{array}{l}\mathrm{pl}+\mathrm{grt}+ \\
\mathrm{pyr}+\mathrm{qtz}\end{array}$ & & & bt $(2-3 \%)$ \\
\hline $\begin{array}{l}\text { Accessory } \\
\text { minerals }\end{array}$ & $\operatorname{mag}(<1 \%)$ & $\operatorname{mag}(<1 \%)$ & $\operatorname{mag}(<1 \%)$ & $\begin{array}{l}\operatorname{mag}(2-3 \%) \text { : } \\
\text { spl (rare) }\end{array}$ & $\begin{array}{l}\operatorname{mag}(1 \%) \text { : } \\
\text { spl (rare) }\end{array}$ & $\operatorname{mag}(1-2 \%)$ & & $\begin{array}{l}\operatorname{mag}(1-2 \%) \text { : } \\
\text { spl (rase): } \\
\text { ap (rare) }\end{array}$ \\
\hline Lithology & Clinopyroxene granulite & Clinopyroxene granulite & Clinopyroxene granulite & $\begin{array}{l}\text { Two-pyroxene } \\
\text { granalite }\end{array}$ & $\begin{array}{l}\text { Clinopyroxene } \\
\text { granulite }\end{array}$ & $\begin{array}{l}\text { Clinopyroxene } \\
\text { granalite }\end{array}$ & $\begin{array}{l}\text { Clinopyroxene } \\
\text { granulite }\end{array}$ & $\begin{array}{l}\text { Clincpyroxene } \\
\text { granulite }\end{array}$ \\
\hline
\end{tabular}

Mineral symbols: cpx-clinopyroxene, opx-orthopyroxene, atp-antiperthite, amp-amphibole, pyr-pyroxene, others after Kretz (1983). 


\subsubsection{Polyphase structural deformation}

In a regional scale, the granulite and the surrounding rocks are fault-bounded. Polyphase structural deformation was recorded in the Weiya granulite. The first stage deformation $\left(\mathrm{D}_{1}\right)$ is characterized by sub-upright folds $\left(\mathrm{F}_{1}\right)$ with $\mathrm{E}-\mathrm{W}$-striking foliation $\left(\mathrm{S}_{1}\right)$ dipping $\sim 70^{\circ}$ toward the south and lineation $\left(\mathrm{L}_{1}\right)$ plunging toward the south. It caused strong ductile shearing of pyroxene and garnet grains and yielded some deformation structures, including (1) irregular margin of pyroxene, garnet, feldspar and quartz minerals (Fig. 4B), (2) deformed pyroxene-twin lamellae, (3) rotated garnet with asymmetric tails (Fig. 4D), and (4) coremantle structure and dynamically recrystallized grains of pyroxene ( Fig. 4B, F). These structures imply that ductile deformation at pyroxene and garnet shearing depths took ever place in the Weiya area along the AWSZ. The asymmetric garnet porphyroclastic system and garnet 'snowball' structure indicate a top-to-the-north shear movement.

The second stage ductile deformation $\left(\mathrm{D}_{2}\right)$ is characterized by inclined folds $\left(\mathrm{F}_{2}\right)$ and feldsparquartz mylonite with foliation $\left(\mathrm{S}_{2}\right)$ dipping to the south and lineation $\left(\mathrm{L}_{2}\right)$ plunging to the south. The axial-plane of folds is parallel to the foliation of the feldspar-quartz mylonite. Flattened, elongated and folded plagioclase-quartz grains (Fig. 4H) are common. The $\sigma$-type feldspar-quartz porphyroclastic system and 'fish-tail-type' mica on the XZ plane indicate a thrust movement toward the north.

At several places near the Weiya granulite, a dextral strike-slip ductile shear deformation was observed, which is marked by sub-vertical foliation and sub-horizontal lineation (Shu et al., 2002). This is the third stage deformation $\left(D_{3}\right)$. It cuts $D_{1}$ and $D_{2}$ structures. For example, at N41 ${ }^{\circ} 42^{\prime} 19^{\prime \prime}$ latitude and E94 $30^{\prime} 48^{\prime \prime}$ longitude (GPS located), the sheared foliation in the mica-quartz-schist is very steep, dipping $80^{\circ}$ toward $\mathrm{N} 20^{\circ} \mathrm{W}$, and the stretching lineation is sub-horizontal, plunging $5^{\circ}$ toward $\mathrm{N} 70^{\circ} \mathrm{E}$. The observed asymmetric feldspar-quartz porphyroclastic system and $\mathrm{S}-\mathrm{C}$ composite foliation on the $\mathrm{XZ}$ plane indicate a dextral strikeslip sense of shear.

After the three stages of deformation, the Weiya granulite was affected by granite emplacement, which caused local contact thermal metamorphism, forming cordierite and wollastonite minerals, which were observed in the samples near the granitoids intrusion. Some rocks suffered from strong hydrothermal alterations, which make the identification of deformation features difficult. 

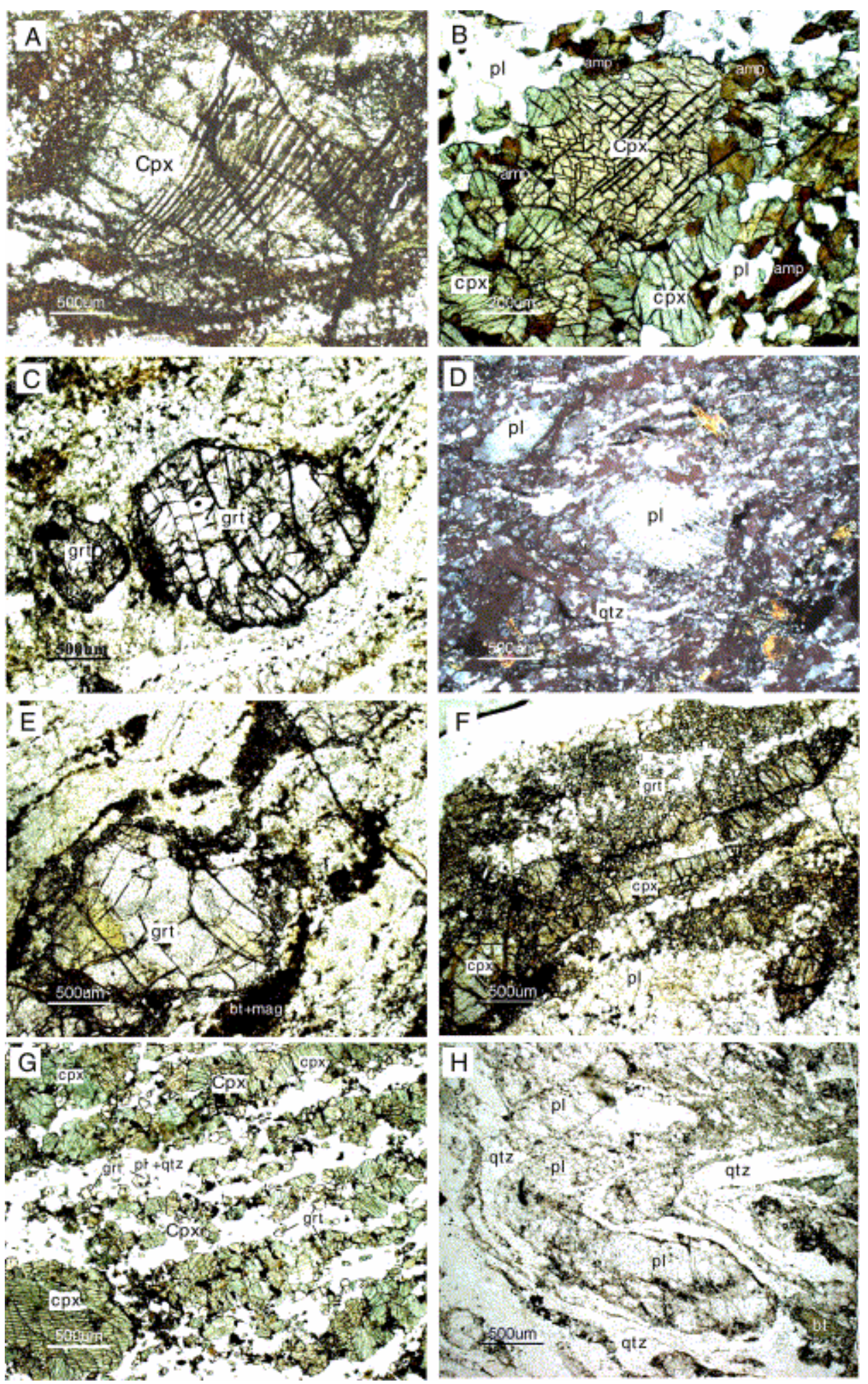

Fig. 4. Micro-photographs showing the microstructure and mineral texture of the Weiya and the Yushugou granulites. (a) Deformed twin lamellae of clinopyroxene in Sample 291 from Yushugou (in plane polarized light). (b) Core-mantle structure of pyroxene in Sample 324 from Weiya (in plane polarized light). (c) Augen garnet in Sample 99107 from Yushugou (in plane polarized light). (d) $\sigma$-type plagioclase in Sample 327 from Weiya (in crossed polar). (e) Augen garnet and banded structure in Sample 99104 from Yushugou (in plane polarized light). (f) Core-mantle structure of pyroxene and banded structure in Sample 97103 from Weiya (in plane polarized light). (g) Dynamically crystallized pyroxene and banded structure in Sample 291 from Yushugou (in plane polarized light). (h) Ribbon structure of quartz and micro-folds in Sample 327 from Weiya (in plane polarized light). Scale bar at left-bottom of each photo is $0.5 \mathrm{~mm}$ long except for photo b $(0.2 \mathrm{~mm})$. 


\subsection{Yushugou granulite}

\subsubsection{Geological features}

The NW-SE-striking Yushugou granulite is located $15 \mathrm{~km}$ west to Kumux, Toksun County and is distributed as fault-bounded slabs in the Yushugou ophiolitic mélange (Fig. 3). The Yushugou ophiolite is composed of meta-peridotite, serpentinite, pyroxenite, meta-gabbro, spilite, felsic rocks, marble, meta-graywacke and amphibole-schist; its petrological features have been previously described ( Allen et al., 1993a). To the east and west of the Yushugou section ( Fig. 3, lower), the thickness of granulite varies from more than $1000 \mathrm{~m}$ to less than ten meters, even vanishing in some places.

Three types of granulitic structure were observed, namely porphyroblastic, banded and massive. In the porphyroblastic granulite, garnet grains with asymmetric rotated structure are up to 1-2 $\mathrm{mm}$ in diameter. The banded granulite is composed of the retrograded amphibole layers, garnet-pyroxene layers and garnet-amphibole layers; each layer varies from 2 to $5 \mathrm{~mm}$ in thickness. The massive granulite in the study area is equigranular and is characterized by very small grain size $(<0.1 \mathrm{~mm})$.

\subsubsection{Two-phase ductile deformation}

Structures of the first stage ductile deformation $\left(\mathrm{D}_{1}\right)$ consist of sub-upright close folds $\left(\mathrm{F}_{1}\right)$ with the axial plane dipping $70^{\circ}$ toward the NE; the foliation $\left(\mathrm{S}_{1}\right)$ was involved in this folding and associated with ductile shear in the pyroxene and garnet grains.

During $\mathrm{D}_{1}$ stage, some microstructures developed in the garnet and pyroxene minerals, including (1) deformed pyroxene-twin lamellae (Fig. 4A), (2) core-mantle structure of pyroxene, (3) augen and asymmetric garnet porphyroclastic system ( Fig. 4C, E), (4) flattened, elongated and oriented garnet and pyroxene grains ( Fig. 4G), (5) dynamically recrystallized pyroxene grains. These structures suggest that the ductile deformation at pyroxene and garnet shearing depths also happened in the Yushugou area.

The second stage ductile deformation $\left(\mathrm{D}_{2}\right)$ is characterized by inclined and recumbent folds $\left(F_{2}\right)$ that overprinted the $F_{1}$, and is associated with foliation and lineation $\left(\mathrm{S}_{2}-\mathrm{L}_{2}\right)$. The $\mathrm{F}_{2}$ folds are asymmetric with a SE-striking hinge parallel to the foliation $\left(\mathrm{S}_{2}\right)$ of feldspar-quartz mylonite. The recrystallized grains of feldspar-quartz around large pyroxene porphyroclasts were formed during retrograde metamorphism, implying a structural level more shallow than that for the formation environment of granulite.

During $\mathrm{D}_{2}$ stage, deformed rocks yielded NE-plunging stretching lineation on the inclined foliation plane. Some ductile microstructures of feldspar-quartz grains were produced in the deformed rocks. They consist mainly of strong undulate extinction of feldspar and quartz, curved plagioclase-twin lamellae, core-mantle structure, aggregates of feldspar-quartz grains, 'book-inclined' structure, and $\sigma$-type asymmetric feldspar-quartz porphyroclastic system. The second stage structures overprinted other garnet-pyroxene deformation structures and may are formed during the exhumation of granulite.

Moreover, $D_{1}$ and $D_{2}$ were overprinted by the third stage deformation $\left(D_{3}\right)$ characterized by brittle cleavages perpendicular to $S_{2}$ and by a series of brittle faults dipping to the northeast. 
These brittle faults and cleavages may have formed during Cenozoic intracontinental thrusting deformation (Shu et al., 2002).

\section{Petrography of granulites}

\subsection{The Weiya granulite}

Thin sections of 48 samples from the Weiya granulite were observed under microscope. Their petrographic features are summarized in Table 1. Rock types of the Weiya granulite include dark clinopyroxene-orthopyroxene granulite, garnet-clinopyroxene granulite and light clinopyroxene granulite. The porphyroblastic and fine-grained textures along with the banded and massive structures are developed in these rocks. In the granulite with porphyroblastic texture, porphyroblastic minerals are mainly clinopyroxene and garnet, with minor orthopyroxene and plagioclase ( Fig. 4B). The groundmass grains occupy $65-75 \mathrm{vol} \%$ of the whole rock and are mainly composed of fine grains $(<0.1 \mathrm{~mm})$ of pyroxene, garnet, feldspar and quartz. The porphyroblasts are commonly $0.5-1.5 \mathrm{~mm}$ in diameter, and the largest is more than $2 \times 3 \mathrm{~mm}$. These porphyroblasts often exhibit core-mantle and augen structure (Fig. 4B), reflecting a ductile deformation signature. Some porphyroblastic garnets and clinopyroxenes contain a few relicts of plagioclase, quartz and biotite. Fine-grained granulites exhibit massive and banded structures. In banded granulites, fine mafic minerals and felsic minerals are concentrated separately forming the banded structure ( Fig. 4F). These bands had strongly been folded by a late deformation event ( Fig. 4H).

All granulites were affected by retrograde metamorphism. Amphibole is the most common retrograde metamorphic phase. It may occur as porphyroblasts or fine grains. Fine-grained amphibole porphyroblasts are distributed around pyroxene or garnet and may replace them. Fine epidote, biotite and muscovite that occur in the groundmass and around large pyroxene and garnet minerals should also be the products of retrograde metamorphism. In addition, a few high-temperature and low-pressure metamorphic minerals, such as cordierite and wollastonite, are observed in samples 9798 and 97101, cutting clinopyroxene or garnet porphyroblasts, which suggests that they were formed during post-tectonic contact metamorphism caused by intrusion of Late Paleozoic granitic magma.

In combination with petrographic observations, three paragenetic phases can be distinguished: the $\mathrm{M}_{1}=$ plagioclase+quartz+biotite $(\mathrm{Pl}+\mathrm{Qtz}+\mathrm{Bt})$, the $\mathrm{M}_{2}=$ clinopyroxene+garnet + plagioclase + quartz + antiperthite \pm orthopyroxene $(\mathrm{Cpx}+\mathrm{Grt}+\mathrm{P} 1+\mathrm{Qtz}+\mathrm{Atp} \pm \mathrm{Opx})$, and the $\mathrm{M}_{3}=$ amphibole + epidote + plagioclase + biotite + quartz $(\mathrm{Amp}+\mathrm{Ep}+\mathrm{Pl}+\mathrm{Bt}+\mathrm{Qtz})$. The $\mathrm{M}_{1}$ assemblage consists of relict minerals, representing a pre-peak metamorphic mineral assemblage. The $\mathrm{M}_{2}$ assemblage was formed during peak granulite facies metamorphism. Of them, hypersthene (Hyp) modal abundance varies from $>10 \%$ to $<1 \%$. Cavernous garnet is distributed among clinopyroxene porphyroblasts (Samples 9738, 9739). Quartz occurs as myrmekite in Kfeldspar (Sample 97101). The $\mathrm{M}_{3}$ assemblage occurs as symplectite or fine grains surrounding $\mathrm{M}_{2}$ minerals (Samples 9798, 97101, 97103), and belongs to the products of retrograde metamorphism.

\subsection{The Yushugou granulite}

The petrographic features of the Yushugou granulites are summarized in Table 1. They commonly show porphyroblastic and banded structures. The porphyroblasts include 
clinopyroxene, garnet, plagioclase and rarely orthopyroxene, while the groundmass consists of fine-grained pyroxene, garnet, plagioclase and quartz ( Table 1). Garnet and clinopyroxene porphyroclasts are up to $1 \times 1.5 \mathrm{~mm}^{2}$ in size and contain small rounded olivine inclusions (Samples 296, 99102), implying that these porphyroblasts may have formed from maficultramafic rocks during high grade metamorphism. Amphibole occurs as porphyroblasts in some samples. The banded granulite consists of thin bands of amphibole schist and garnetamphibole plagioclase gneiss, which are ascribed to retrograde metamorphism and ductile deformation. The core-mantle structure was well developed between porphyroblasts and dynamically recrystallized pyroxene and garnet grains (Fig. 4C, G). The feldspar-quartz facies ductile shear is also common. The accessory minerals, including Ti-magnetite, spinel and apatite, total up to $1-3 \mathrm{vol} \%$, and Ti-magnetite (or ilmenite) locally up to $2-3 \mathrm{vol} \%$ in some samples, e.g. Sample 294.

There are two phases of mineral assemblages in the Yushugou granulites: $\mathrm{M} 1=\mathrm{Cpx}+\mathrm{Grt}+\mathrm{Pl} \pm \mathrm{Hyp}$, and $\mathrm{M}_{2}=\mathrm{Amp}+\mathrm{P} 1+\mathrm{Qtz} \pm \mathrm{Bt}$. The minerals in the former assemblage may occur as porphyroblasts, and were formed during peak metamorphism. The minerals in the latter assemblage are finer in size, and dispersed within groundmass or surrounding the $\mathrm{M}_{1}$ minerals. The $\mathrm{M}_{2}$ assemblage was formed during retrograde metamorphism following a peak in temperature. Locally, epidote and chlorite veins, $2-3 \mathrm{~mm}$ in thickness, are distributed in fissures of granulite, which were produced by the latest hydrothermal alteration.

\section{Analytical methods for geochronology and geochemistry}

All analyses for rock and mineral compositions were carried out at the State Key Laboratory for Mineral Deposits Research, Nanjing University. All samples used for analyses are fresh, not-fractured and least altered. The chemical compositions of minerals of the various metamorphic rocks were analyzed using the JXA-8800M Electron Microprobe (EMP) with a $15 \mathrm{keV}$ accelerating voltage and $20 \mathrm{nA}$ beam current. The 38 sets of EMP analyzed minerals are listed in Table 3. The results have been corrected using natural mineral standards.

The $T-P$ conditions of the granulites, based on various geothermobarometers (Ai, 1994; Ravna, 2000; Wells, 1977; Wood and Banno, 1973; Nickel and Green, 1985; Newton and Perkins, 1982; Hoisch, 1989 and Whitney and Stormer, 1977), were calculated from the EMP compositions of various minerals.

Major element concentrations of granulites were analyzed with wet chemical methods. Trace elements, including rare earth elements (REE), were analyzed by ICP-AES. Analysis precision for most trace elements is $10-20 \%$, but analytical errors for $\mathrm{Nb}$, Ta, $\mathrm{Hf}$ and $\mathrm{Th}$ may be over $30 \%$ due to their very low concentrations in mafic granulites.

Sm-Nd isotope analyses of plagioclase, clinopyroxene separates and whole rocks of the Weiya granulite (No. 99) were performed by Zhang Rengu on a VG-354 mass spectrometer at the Isotopic Laboratory, Institute of Geology (Beijing), Academia Sinica. The detailed procedure for analysis of isotopic compositions is the same as described by DePaolo (1988). $\mathrm{Sm}$ and $\mathrm{Nd}$ concentrations were determined by the isotopic dilution method. Uncertainties reported here represent $2 \sigma$ errors. The $\mathrm{Nd}$ isotopic fractionation during measuring is corrected by normalization to ${ }^{146} \mathrm{Nd} /{ }^{144} \mathrm{Nd}=0.7219$. The decay constant used to calculate the radiogenic age is: $\lambda\left({ }^{147} \mathrm{Sm}\right)=6.54 \times 10^{-12} \mathrm{a}^{-1}$. The blanks of $\mathrm{Sm}$ and $\mathrm{Nd}$ of the whole experimental procedure are $5 \times 10^{-11} \mathrm{~g}$. Measurement of the La Jolla Nd standard yields ${ }^{143} \mathrm{Nd} /{ }^{144} \mathrm{Nd}$ of $0.511851 \pm 3(2 \sigma)$. The age calculation adopts the York regression method. 
An amphibole sample was separated from the Weiya granulite (No. 9738) for ${ }^{40} \mathrm{Ar} /{ }^{39} \mathrm{Ar}$ dating. The rock was first crushed by hand into grains $0.1-0.25 \mathrm{~mm}$ in diameter, then panned and magnetically separated, and finally the amphibole grains were handpicked. The purity of the sample is greater than $98 \%$. Ar isotope analysis was performed by Sang Haiqing using the RGA-10 mass spectrometer (VSS Company, Britain) at the Isotopic Laboratory, Institute of Geology (Beijing), Academia Sinica. The analytical method and procedure for progressive out-gassing of the mineral population are the same as those described in detail by Monie et al., 1994 and McDougall and Harrison, 1988.

\section{Metamorphic age of the Weiya granulite}

\subsection{Sm-Nd inner isochron age}

The $\mathrm{Sm}-\mathrm{Nd}$ isotopic compositions of plagioclase and clinopyroxene separates along with whole rock analyses of the Weiya granulite (No. 99) yielded a reasonable Sm-Nd inner isochron (Fig. 5A). The isochron age obtained using the York linear regression method is $538 \pm 24 \mathrm{Ma}$. The MSWD value (1.2) was calculated with an error of $0.5 \%$ for ${ }^{147} \mathrm{Sm} /{ }^{144} \mathrm{Nd}$ and relative error of $8 \times 10^{-5}$ for ${ }^{143} \mathrm{Nd} /{ }^{144} \mathrm{Nd}$ (Table 2). This age is considered to be the time of peak metamorphism possibly related to plate subduction due to the high block temperature of $\mathrm{Sm}-\mathrm{Nd}$ isotope in these minerals and whole rocks. The age indicates that the Weiya granulite formed during the latest Precambrian, and hence its protolith was formed before $540 \mathrm{Ma}$. Whole rock $\mathrm{Sm}-\mathrm{Nd}$ isotopic analysis of Weiya granulite Sample 99 yielded an older $\mathrm{Nd}$ model age $\left(T_{\mathrm{DM}}=\sim 2.3 \mathrm{Ga}\right)$. Assuming that the protolith of this granulite was not contaminated by ancient crustal materials after formation, as suggested by the geochemistry (see below), the model age may represent the time when the primitive mafic magma was generated from a depleted mantle. This age is somewhat close to the age of the Fuping Complex in North China, which was originated as a magmatic arc related to oceanic subduction and collision (Liu et al., 2002), providing a clue to Precambrian crustal evolution in the Tianshan region.

Table 2. Sm-Nd and ${ }^{40} \mathrm{Ar}-{ }^{39} \mathrm{Ar}$ isotopic analysis results of the Weiya granulite

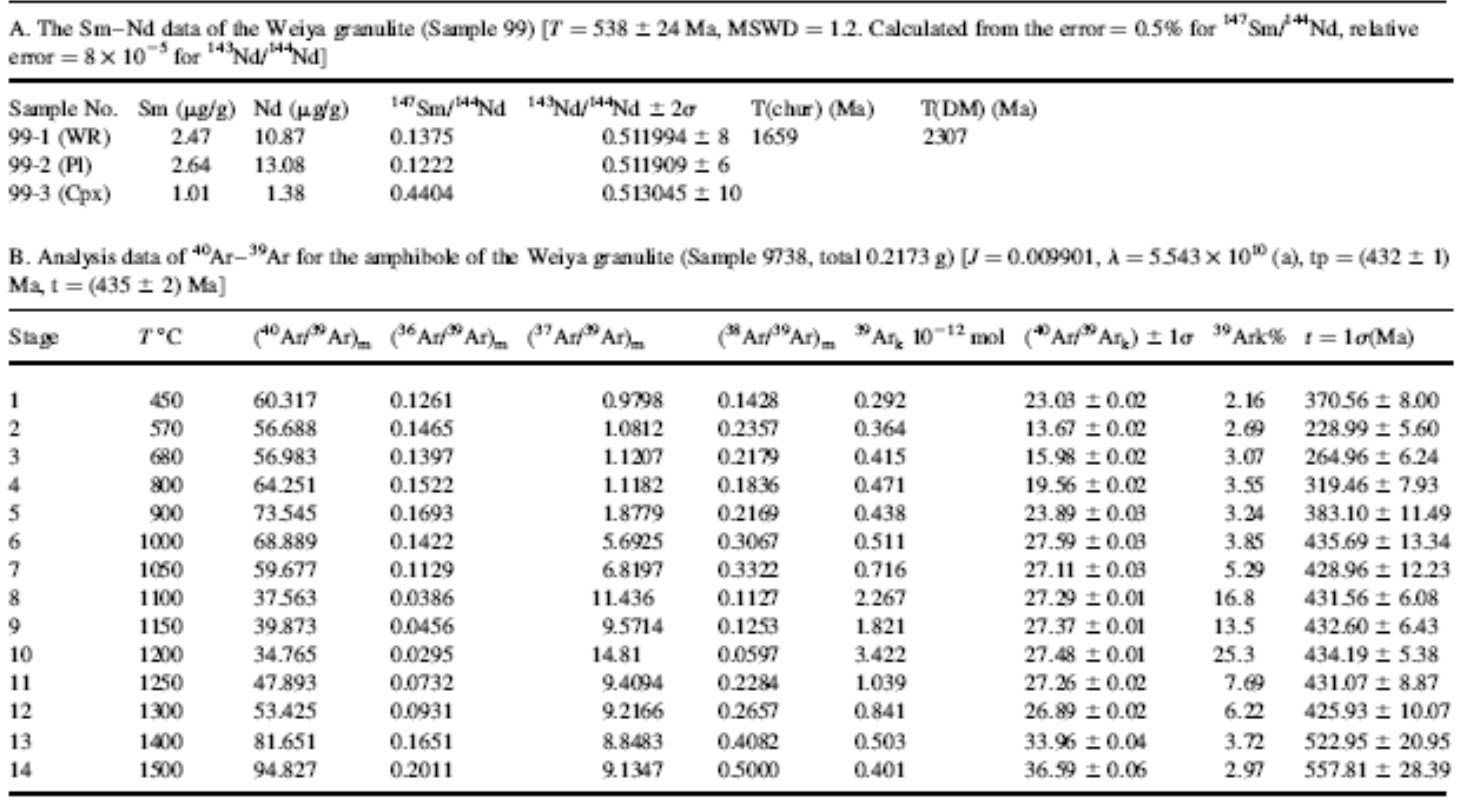



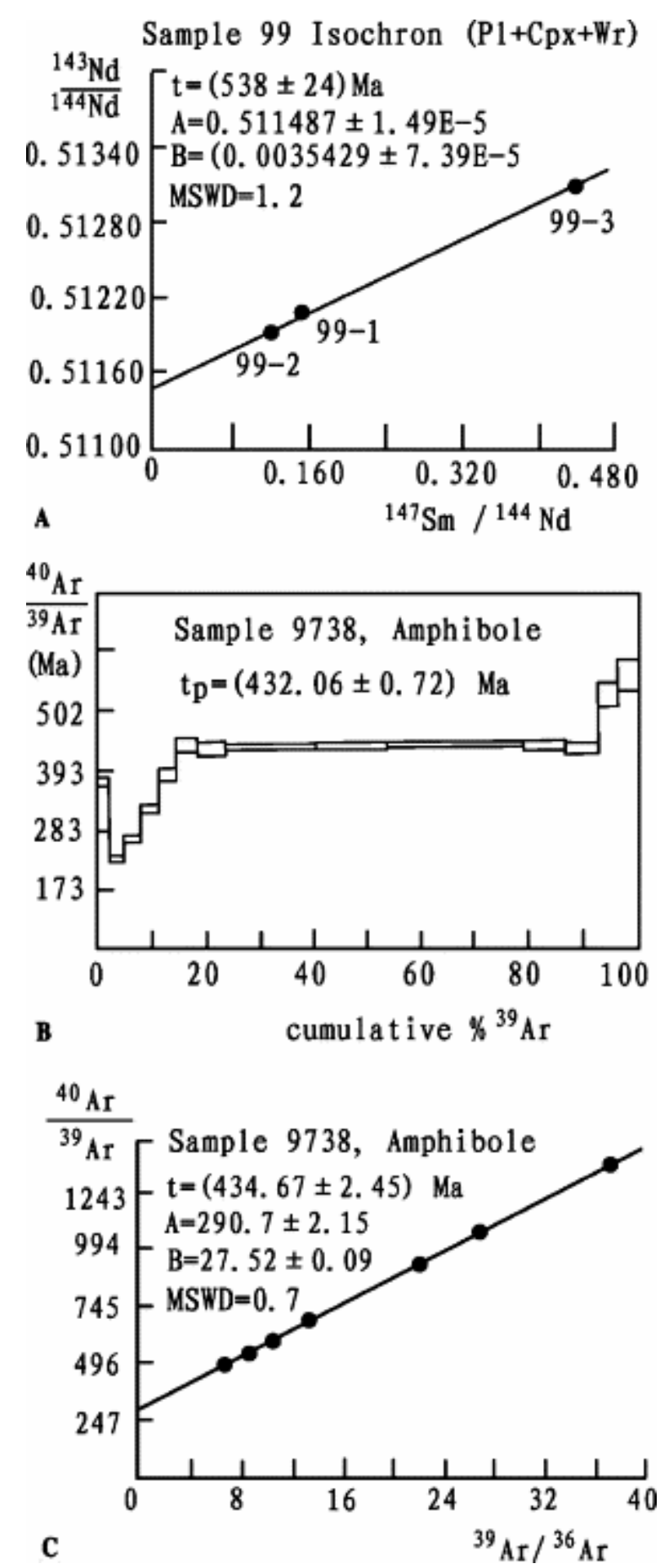

Fig. 5. Diagrams showing the results of isotopic dating for the Weiya granulite. (A) Sm-Nd isochron age; (B) ${ }^{40} \mathrm{Ar}-{ }^{39} \mathrm{Ar}$ plateau age; (C) ${ }^{40} \mathrm{Ar}-{ }^{39} \mathrm{Ar}$ isochron age.

\subsection{Amphibole ${ }^{40} \mathrm{Ar} /{ }^{39} \mathrm{Ar}$ dating}

The age-spectra of the amphibole separates (N0. 9738) show a well-marked plateau corresponding to the largest percentage of Ar gas release; the plateau age and percentage curve of argon loss are presented in Fig. 5B. This sample yielded a very coincident age spectral diagram, suggesting that the largest Ar diffusion domain remained a closed system 
since formation of the amphibole. Therefore the plateau age may be interpreted as the time of formation. From the progressive release of Ar gas, the Weiya granulite yielded an amphibole plateau age of $432 \pm 1 \mathrm{Ma}$ ( Fig. 5B) and an isochron age of $435 \pm 2 \mathrm{Ma}$ ( Fig. 5C), indicating an early Paleozoic tectonothermal event followed by exhumation. Petrographical features show that the amphibole is the product of retrograde metamorphism; hence this age represents the time of retrograde metamorphism. Che et al. (1994) reported a $\mathrm{Rb}-\mathrm{Sr}$ isochron age of $468 \mathrm{Ma}$ for gabbro from the Mishigou ophiolite, $\mathrm{Gu}$ et al. (1990) obtained 470 $\pm 3.0 \mathrm{Ma}(\mathrm{Rb}-\mathrm{Sr}$ ) for a monzogranite in the central Tianshan sub-belt, and Hopson et al. (1989) reported an important granitoids magmatism event (435 Ma) in this area. All these data demonstrate that there was a strong tectonothermal event during the early Paleozoic (435-468 Ma) in the central Tianshan region, which was related to retrograde metamorphism of the granulites.

\section{Mineral compositions and $P-T$ condition estimates}

\subsection{The mineral compositions}

The results of electronic microprobe analyses of some samples are listed in Table 3 . The analyzed minerals include clinopyroxene, orthopyroxene, garnet, amphibole, plagioclase, biotite, muscovite and potassic feldspar. The analytical results show that clinopyroxenes in both basic and intermediate granulites are sahlite, and orthopyroxenes are hypersthene. Garnets of most granulites have 45.0-52.8\% almandine, 15.9-24.5\% pyrope and 25.0-32.6\% grossularite (Table 3), except for Samples 9798 and 99102. Compared with the granulites from other locations worldwide, garnets of the eastern Tianshan granulites are characterized by high $\mathrm{CaO}$ contents $(8.72-12.63 \%)$.

Table 3. The EMP mineral compositions of representative samples and $T-P$ condition estimates

\begin{tabular}{|c|c|c|c|c|c|c|c|c|c|c|c|c|c|c|c|c|c|c|c|}
\hline \multirow{3}{*}{$\begin{array}{l}\text { Location } \\
\text { Samples } \\
\text { Minerads }\end{array}$} & \multicolumn{19}{|c|}{ Weiya granulites } \\
\hline & \multicolumn{4}{|l|}{9786} & \multicolumn{5}{|l|}{9739} & \multicolumn{4}{|l|}{9798} & \multicolumn{4}{|l|}{97101} & \multirow{2}{*}{$\begin{array}{l}97103 \\
g t\end{array}$} & \multirow{2}{*}{$\begin{array}{l}9788 \\
\text { cpx }\end{array}$} \\
\hline & cpx & $\mathrm{grt}$ & $\operatorname{smp}$ & $\mathrm{pl}$ & $\mathrm{Cpx}_{\mathrm{pr}}$ & $\mathrm{grt}$ & $\mathrm{pl}$ & Ms & Bt & opx & grt & erd & $\operatorname{sanp}$ & $\operatorname{smp}$ & $\mathrm{kf}$ & ab & wo & & \\
\hline$\overline{\mathrm{SiO}_{2}}$ & 47.04 & 38.13 & 38.42 & 54.76 & 48.38 & 3954 & 56.25 & 45.90 & 33.45 & 52.74 & 37.16 & 46.72 & 44.13 & 43.84 & 64.56 & 67.54 & 50.79 & 39.94 & 50.24 \\
\hline $\mathrm{TiO}_{2}$ & 0.92 & 0.12 & 2.91 & 0.00 & 0.40 & 0.18 & 0.00 & 0.23 & 1.12 & 0.13 & 1.18 & 0.12 & 1.25 & 1.43 & 0.01 & 0.00 & 0.00 & 0.14 & 0.24 \\
\hline $\mathrm{Al}_{2} \mathrm{O}_{3}$ & 6.95 & 2.21 & 14.88 & 29.34 & 4.95 & 21.60 & 27.99 & 3156 & 17.45 & 1.45 & 6.02 & 33.68 & 10.37 & 13.62 & 19.65 & 1958 & 0.02 & 22.28 & 3.55 \\
\hline $\mathrm{F} \times \mathrm{O}^{*}$ & 11.70 & 21.41 & 17.81 & 0.18 & 12.35 & 22.94 & 0.08 & 5.85 & 23.56 & 20.89 & 21.22 & 7.26 & 18.11 & 1755 & 0.11 & 0.32 & 0.30 & 2.90 & 9.97 \\
\hline $\mathrm{MnO}$ & 0.26 & 1.66 & 0.19 & 0.00 & 0.43 & 0.28 & 0.00 & 0.24 & 0.11 & 0.07 & 0.48 & 0.41 & 0.56 & 0.53 & 0.00 & 0.00 & 0.33 & 0.29 & 0.26 \\
\hline $\mathrm{MgO}$ & 9.94 & 4.07 & 8.58 & 0.03 & 9.69 & 6.32 & 0.00 & 0.85 & 9.99 & 24.12 & 0.30 & 956 & 10.24 & 9.95 & 0.00 & 0.35 & 0.04 & 5.50 & 12.79 \\
\hline $\mathrm{CsO}$ & 22.06 & 12.63 & 11.60 & 10.29 & 23.29 & 8.96 & 9.24 & 0.43 & 1.11 & 0.36 & 3337 & 0.06 & 12.21 & 9.99 & 0.54 & 0.44 & 48.54 & 8.2 & 22.54 \\
\hline $\mathrm{Na}_{2} \mathrm{O}$ & 0.90 & 0.01 & 2.13 & 4.98 & 0.38 & 0.08 & 6.15 & 056 & 0.32 & 0.03 & 0.03 & 0.89 & 1.15 & 1.28 & 2.99 & 10.69 & 0.00 & 0.08 & 0.68 \\
\hline $\mathrm{K}_{2} \mathrm{O}$ & 0.01 & 0.00 & 1.07 & 0.11 & 0.01 & 0.00 & 0.03 & 11.68 & 8.57 & 0.00 & 0.01 & 0.46 & 1.05 & 1.82 & 11.79 & 0.65 & 0.00 & 0.00 & 0.01 \\
\hline Total & 99.77 & 100.24 & 9.99 & 99.67 & 99.88 & 99.90 & 99.72 & 9731 & 95.68 & 99.79 & 99.76 & 99.17 & 99.07 & 99.99 & 99.65 & 9957 & 100.02 & 99.85 & 100.28 \\
\hline $\mathrm{Mg \#}$ & 0.60 & 0.25 & 0.46 & & 0.58 & 0.33 & & 0.21 & 0.43 & 0.67 & 0.02 & 0.70 & 0.50 & 050 & & & & 0.30 & 0.70 \\
\hline Alm, $\mathrm{Fs}, \mathrm{An}$ & 20.3 & 45.0 & & 53.0 & 20.8 & 499 & 453 & & & 325 & 35 & & & & 2.7 & 2.1 & 05 & 51.9 & 16.2 \\
\hline $\mathrm{Spr}, \mathrm{En}, \mathrm{Ab}$ & 30.7 & 3.7 & & 46.4 & 29.0 & 0.6 & 54.6 & & & 66.8 & 1.1 & & & & 27.0 & 94.1 & 0.1 & 0.7 & 37.0 \\
\hline Prp, Wo, Or & 49.0 & 15.9 & & 0.7 & 50.2 & 245 & 0.1 & & & 0.7 & 1.2 & & & & 70.2 & 3.8 & 99.4 & 2.2 & 46.9 \\
\hline Gis & & 32.6 & & & & 25.0 & & & & & 293 & & & & & & & 25.3 & \\
\hline Anr & & 2.9 & & & & & & & & & 65.0 & & & & & & & & \\
\hline$P\left(\mathrm{GP}^{2}\right)$ & 0.5 & 1.0 & 1.5 & 2.0 & 05 & 1.0 & 15 & 2.0 & & & & & & & & & & & \\
\hline$T\left({ }^{\circ} \mathrm{C}\right)^{\circ}$ & 873 & 906 & 939 & 971 & 976 & 1016 & 1055 & 1095 & & & & & & & & & & & \\
\hline$T\left({ }^{\circ} \mathrm{C}\right)$ & 900 & 980 & 1000 & 1050 & 900 & 950 & 1000 & 1050 & & & & & & & & & & & \\
\hline$P\left(\mathrm{GPa}^{\mathrm{b}}\right)^{\mathrm{b}}$ & 1.07 & 1.11 & 1.16 & 1.20 & 1.02 & 1.06 & 1.10 & 1.14 & & & & & & & & & & & \\
\hline$a+b$ & 911 & 1.08 & & 1025 & 1.12 & & & & $650^{\circ}$ & & & & & & $670^{d}$ & & & & \\
\hline Location & $\begin{array}{l}\text { Weiya } \\
\text { granulite }\end{array}$ & & Yushugou & granulites & & & & & & & & & & & & & & & \\
\hline Ssmples & 9738 & & 99107 & & & 99104 & & & & 98294 & & & & 98296 & 99102 & 99106 & & & \\
\hline Minerals & $\mathrm{grt}$ & $\mathrm{Cpx}$ & $\overline{c p x}$ & Git & $\mathrm{PI}$ & $\mathrm{grt}$ & cpx & $\operatorname{anp}$ & $\mathrm{Bt}$ & cpx & op $x$ & $g t$ & $\mathrm{pl}$ & cpx & $\mathrm{grt}$ & cpx & $\mathrm{grt}$ & smp & $\mathrm{pl}$ \\
\hline$\overline{\mathrm{SOO}_{2}}$ & 38.88 & 48.71 & 49.83 & 38.49 & 4652 & 3958 & 49.28 & 43.23 & 38.27 & 49.60 & 52.71 & 39.31 & 57.03 & 48.06 & 39.51 & 48.15 & 37.65 & 39.25 & 54.82 \\
\hline TiC & $\begin{array}{l}30.00 \\
0.22\end{array}$ & 0.52 & 0.28 & & & & & & 0. & 055 & 0.11 & 0.11 & & 0.37 & 0.18 & 0.73 & 0.09 & 2.49 & 0.02 \\
\hline Al2 & 2159 & 4. & 4 & & 34. & 21 & 4. & 12 & 20. & 5.95 & 1.98 & 21.68 & 25.24 & 491 & 22. & 5.49 & 21.98 & 14.94 & 28.88 \\
\hline $\mathrm{F} \odot \mathrm{O}$ & $24 \mathrm{C}$ & 11. & & & 0 & 22 & & & 25. & 10.63 & 20.17 & 21.31 & 0.00 & 12.84 & 24.52 & 1151 & 23.87 & 17.56 & 0.25 \\
\hline Mn & 0.2 & 0. & 0 & 0. & 0. & 0 & 0 & 0 & 0.1 & 0.31 & 0.25 & 13 & 0.00 & 0.64 & 0.18 & 0.15 & 1.18 & 0.13 & 0.02 \\
\hline $\mathrm{MgO}$ & 495 & 10.24 & 10.50 & 4. & 0.21 & 5. & 1031 & 10.38 & 3.8 & 990 & 24.09 & 4.29 & 0.02 & 9.11 & 8.30 & 10.31 & 4.07 & 9.19 & 0.00 \\
\hline $\mathrm{C} s \mathrm{O}$ & 98 & 23. & 2. & 10. & 17. & 10. & 22. & 11. & & 21.63 & 0.1 & 11.16 & 7.59 & 23.81 & 13 & 2231 & 1131 & 11.60 & 9.52 \\
\hline $\mathrm{N} 22 \mathrm{O}$ & 0. & 0. & 0. & 0 & 2 & 0. & & 2. & & 1.09 & & 0.04 & 7.39 & & 0. & 0.80 & 0.02 & 2.26 & 5.83 \\
\hline K2 & 0.00 & 0.00 & & 0.00 & 0.04 & 0.00 & & 0.21 & 6.5 & 0.03 & 0.01 & 0.00 & 0.04 & 0.01 & 0.00 & 0.01 & 0.00 & 0.94 & 0.09 \\
\hline Total & 99.82 & 99.93 & 99.76 & 99.99 & 100.73 & 100.09 & 99.34 & 98.16 & 96.68 & 99.69 & 99.44 & 99.28 & 9.31 & 100.14 & 100.33 & 99.47 & 100.17 & 98.36 & 99.44 \\
\hline Mg\# & 0.27 & 0.61 & 0.64 & 0.26 & & 0.29 & 0.63 & 0.54 & 0.22 & 0.62 & 0.68 & 0.26 & & 056 & 0.38 & 0.61 & 0.23 & 0.48 & \\
\hline Alm, $\mathrm{Fs}, \mathrm{An}$ & 52.6 & 19.6 & 17.9 & 49.7 & 825 & 493 & 18.7 & & & 19.0 & 31.9 & 47.7 & 36.1 & 21.6 & 52.8 & 19.7 & 49.0 & 0.40 & 47.2 \\
\hline
\end{tabular}




\begin{tabular}{|c|c|c|c|c|c|c|c|c|c|c|c|c|c|c|c|c|c|c|}
\hline Sps, En, Ab & 0.5 & 30.8 & 32.1 & 05 & 17.3 & 1.3 & 31.6 & & 31.5 & 67.9 & 3.1 & 63.7 & 27.3 & 0.4 & 31.4 & 2.7 & & 52.3 \\
\hline Prp, Wo, Or & 19.3 & 49.6 & 50.0 & 18.6 & 0.2 & 19.7 & 49.6 & & 49.5 & 0.2 & 17.1 & 0.2 & 51.2 & 31.9 & 48.9 & 16.1 & & 0.5 \\
\hline Grs & 27.6 & & & 28.1 & & 29.7 & & & & & 32.0 & & & 15.0 & & 26.2 & & \\
\hline Anr & & & & 3.0 & & & & & & & & & & & & 6.0 & & \\
\hline$P\left(\mathrm{GP}^{2}\right)$ & 1.0 & 15 & 05 & 1.0 & 1.5 & 0.5 & 1.0 & 15 & 0.5 & 1.0 & 15 & 2.0 & & & 0.5 & 1.0 & 15 & 2.0 \\
\hline$T\left({ }^{\circ} \mathrm{C}\right)^{\circ}$ & 853 & 886 & 788 & 819 & 851 & 844 & 877 & 911 & 832 & 864 & 896 & 929 & & & $m$ & 808 & 839 & 870 \\
\hline$T\left({ }^{\circ} \mathrm{C}\right)$ & & & 800 & 850 & 900 & & & & 800 & 850 & 900 & 960 & & & 800 & 850 & 900 & 990 \\
\hline$P(\mathrm{GPa})^{b}$ & & & 0.90 & 0.92 & 0.94 & & & & 1.05 & 1.10 & 1.16 & 1.21 & & & 0.88 & 0.92 & 0.96 & 1.00 \\
\hline$a+b$ & & & 813 & 0.91 & & & & & 873 & 1.13 & & & & & 801 & 0.88 & & \\
\hline
\end{tabular}

Average temperatures of $\mathrm{Ai}$ (1994); Rava (2000) cpx-grt thermometer

b Newhon and Perkins (1982) cpx-grt-pl-qtz barometer.

${ }^{c}$ Hoisch (1989) ms-bx thermometer.

d Whitney and Stormer (1977) two-feldspar thermometer

Plagioclases in mafic granulites have large composition variations with anorthite contents from 36.1 to 82.5. Albite was observed only in the Weiya intermediate granulite. K-feldspar occurs in the intermediate granulite as fine grains or lamellae in antiperthite. Amphiboles are ferroan pargasite or pargasitic hornblende, and biotites are of Fe-rich with $\mathrm{Mg}$ numbers ranging from 0.22 to 0.43 .

\section{2. $P-T$ condition estimates}

Petrography indicates that the $\mathrm{Cpx}+\mathrm{Grt}+\mathrm{Pl} \pm \mathrm{Opx}$ assemblage in most granulites resulted from peak metamorphism, and thus the temperature and pressure estimated by the Cpx-Grt thermometer and the Grt-Opx and Cpx-Grt-Pl-Qtz barometers might represent peak metamorphism. Two new Grt-Cpx thermometers (Ai, 1994 and Ravna, 2000) yielded very consistent temperature estimates, and their average values indicate that peak metamorphism for the granulite took place at $800-1050{ }^{\circ} \mathrm{C}$, while the Weiya granulite experienced higher temperatures $\left(>900^{\circ} \mathrm{C}\right)$ than the Yushugou granulite $\left(<900^{\circ} \mathrm{C}\right)($ Table 3$)$. However, cpx-opx thermometers (Wells, 1977 and Wood and Banno, 1973) and the Grt-Opx barometer ( Nickel and Green, 1985) yielded much lower temperatures $\left(737,695^{\circ} \mathrm{C}\right)$ and an exceptionally high pressure estimate $(1.8 \mathrm{GPa})$ for Sample 98294 , which is inconsistent with granulite facies metamorphism. This may imply that the orthopyroxene was not in equilibrium with clinopyroxene and garnet and was affected by the retrograde metamorphism. Cpx-Grt-Pl-Qtz barometers ( Newton and Perkins, 1982) yielded reasonable pressure values. A combination of Grt-Cpx temperatures with Cpx-Grt-Pl-Qtz pressures suggests that the Weiya granulites were formed under $T-P$ conditions of $910-1025^{\circ} \mathrm{C}$ and $1.08-1.12 \mathrm{GPa}$, and the Yushugou granulites under conditions of $800-870{ }^{\circ} \mathrm{C}$ and $0.88-1.13 \mathrm{GPa}$. These data are similar to the results of Shu et al. $\left(813{ }^{\circ} \mathrm{C}, 1.5 \mathrm{GPa}, 1996\right)$ and Wang et al. $\left(795-964{ }^{\circ} \mathrm{C}, 0.97-1.42 \mathrm{GPa}\right.$, 1999), indicating that the eastern Tianshan granulites were formed at relatively high pressures and high temperatures, reflecting a geological environment involving deep-derived thermal fluids during late Precambrian crustal evolution.

Amphibole, biotite, muscovite and K-feldspar lamellae in antiperthite are the products of retrograde metamorphism. The Ms-Bt thermometer (Hoisch, 1989) and the two-feldspar thermometer ( Whitney and Stormer, 1977) yielded estimates of 650 and $670{ }^{\circ} \mathrm{C}$ for this stage of metamorphism, reflecting upper amphibolite facies retrograde metamorphism related to a late exhumation event in this region.

\section{Geochemistry and geological implications}

\subsection{Major and trace element features of the granulites}

Seven representative samples from the Weiya and eight from the Yushugou were chosen for major and trace element analyses. The results are listed in Table 4. 
Table 4. Major and trace element compositions of the Weiya and Yushugou granulites

\begin{tabular}{|c|c|c|c|c|c|c|c|c|c|c|c|c|c|c|c|}
\hline & \multicolumn{7}{|c|}{ Weiya granulites } & \multicolumn{8}{|c|}{ Yushugou granulites } \\
\hline & 9738 & 9786 & 9788 & 9739 & 9798 & 97101 & 97103 & 99100 & 99102 & 99104 & 99105 & 99107 & 291 & 294 & 296 \\
\hline $\mathrm{SiO}_{2}$ & 47.45 & 49.12 & 50.43 & 48.1 & 61.35 & 60.83 & 66.47 & 48.03 & 47.68 & 45.96 & 47.37 & 47.34 & 46.03 & 45.26 & 45.32 \\
\hline $\mathrm{TiO}_{2}$ & 0.69 & 0.82 & 1.40 & 0.92 & 0.34 & 0.6 & 0.44 & 156 & 1.38 & 1.26 & 1.26 & 1.65 & 1.99 & 1.76 & 1.71 \\
\hline $\mathrm{Al}_{2} \mathrm{O}_{3}$ & 14.62 & 14.21 & 12.79 & 14.78 & 15.7 & 15.24 & 13.14 & 15.13 & 15.76 & 16.15 & 14.34 & 14.89 & 12.63 & 13.38 & 13.66 \\
\hline $\mathrm{Fe}_{2} \mathrm{O}_{3}$ & 4.03 & 4.37 & 2.85 & 4.53 & 2.85 & 2.76 & 1.76 & 3.87 & 4.34 & 4.13 & 5.68 & 3.99 & 451 & 4.53 & 4.45 \\
\hline $\mathrm{FeO}$ & 5.89 & 6.92 & 7.55 & 6.64 & 4.34 & 4.32 & 4.34 & 7.16 & 6.38 & 6.58 & 8.13 & 6.74 & 8.65 & 9.07 & 8.16 \\
\hline $\mathrm{MmO}$ & 0.19 & 0.21 & 0.22 & 0.09 & 0.12 & 0.12 & 0.23 & 0.2 & 0.23 & 0.21 & 0.21 & 0.18 & 0.22 & 0.23 & 0.20 \\
\hline $\mathrm{MgO}$ & 6.78 & 6.16 & 5.23 & 5.95 & 4.86 & 2.36 & 6.18 & 5.89 & 6.24 & 6.12 & 4.96 & 7.34 & 6.79 & 6.57 & 7.18 \\
\hline $\mathrm{CaO}$ & 16.86 & 14.22 & 14.41 & 15.41 & 3.73 & 6.12 & 3.55 & 15.23 & 13.79 & 14.68 & 15.12 & 14.35 & 1453 & 14.96 & 14.99 \\
\hline $\mathrm{Na}_{2} \mathrm{O}$ & 2.18 & 2.56 & 2.25 & 1.12 & 3.96 & 4.00 & 0.97 & 1.89 & 2.01 & 2.1 & 1.34 & 1.65 & 2.77 & 2.19 & 2.16 \\
\hline $\mathrm{K}_{2} \mathrm{O}$ & 0.22 & 0.51 & 1.26 & 0.57 & 2.33 & 1.86 & 1.57 & 0.23 & 0.27 & 0.41 & 0.57 & 0.35 & 0.24 & 0.51 & 0.67 \\
\hline $\mathrm{P}_{2} \mathrm{O}_{5}$ & 0.15 & 0.07 & 0.19 & 0.23 & 0.34 & 0.29 & 0.09 & 0.09 & 0.12 & 0.09 & 0.08 & 0.12 & 0.16 & 0.07 & 0.08 \\
\hline LOI & 0.58 & 1.28 & 1.13 & 1.52 & 1.23 & 1.39 & 1.56 & 1.07 & 1.69 & 1.87 & 1.13 & 1.33 & 1.36 & 1.86 & 1.88 \\
\hline Total & 99.64 & 100.45 & 99.71 & 99.86 & 101.15 & 99.89 & 100.3 & 100.35 & 99.89 & 99.56 & 100.19 & 99.93 & 99.88 & 100.39 & 100.46 \\
\hline $\mathrm{Rb}$ & 45 & 48 & 54 & 62 & 56 & 62 & 64 & 55 & 70 & 54 & 56 & 64 & 63 & 58 & $\$ 2$ \\
\hline St & 165 & 200 & 212 & 252 & 586 & 615 & 632 & 186 & 179 & 192 & 212 & 172 & 226 & 218 & 202 \\
\hline $\mathrm{Ba}$ & 168 & 195 & 231 & 235 & 478 & 498 & 516 & 12 & 135 & 118 & 134 & 128 & 118 & 121 & 113 \\
\hline $\mathrm{Th}$ & 18 & 12 & 14 & 11 & 10 & 12 & 12 & 1 & 10 & 12 & 11 & 12 & 10 & 1 & 10 \\
\hline $\mathrm{Nb}$ & 46 & 52 & 48 & 49 & 26 & 28 & 32 & 54 & 49 & 58 & 44 & 48 & 56 & 65 & 62 \\
\hline $\mathrm{Ta}$ & 3.58 & 4.1 & 3.86 & 35 & 1.65 & 1.8 & 2.24 & 5.3 & 4.23 & 5.24 & 4.65 & 6.05 & 5.12 & 6.21 & 6.4 \\
\hline $\mathrm{Zr}$ & 55 & 49 & 58 & 65 & 128 & 136 & 148 & 53 & 68 & 48 & 54 & 56 & 48 & 66 & 68 \\
\hline Hf & 4.25 & 5.6 & 4.7 & 4.35 & 2.18 & 2.86 & 3.25 & 4.85 & 5.36 & 5.7 & 5.54 & 4.9 & 4.84 & 5.14 & 5.4 \\
\hline $\mathbf{Y}$ & 22.68 & 24.34 & 29.56 & 33.65 & 10.28 & 13.12 & 20.87 & 26.86 & 27.1 & 26.86 & 37.14 & 32.8 & 27.17 & 26.6 & 20.44 \\
\hline La & 1.23 & 1.35 & 1.91 & 2.17 & 25.21 & 25.74 & 35.94 & 4.90 & 4.11 & 3.81 & 5.42 & 4.48 & 5.63 & 3.67 & 3.66 \\
\hline $\mathrm{Ce}$ & 3.07 & 3.19 & 4.19 & 4.82 & 43.34 & 47.80 & $n .69$ & 14.12 & 13.36 & 13.13 & 17.84 & 15.83 & 14.78 & 10.07 & 10.27 \\
\hline $\mathrm{Pt}_{\mathrm{t}}$ & 0.40 & 0.41 & 0.55 & 0.62 & 7.54 & 7.68 & 10.91 & 2.98 & 2.76 & 2.52 & 3.52 & 3.12 & 3.18 & 2.39 & 2.19 \\
\hline Nd & 1.71 & 1.90 & 2.30 & 2.64 & 24.34 & 25.59 & 42.15 & 14.06 & 13.36 & 11.76 & 16.18 & 14.58 & 14.15 & 10.02 & 9.17 \\
\hline $\mathrm{Sm}$ & 0.54 & 0.61 & 0.88 & 0.96 & & 4.79 & & & 3.79 & 3.21 & 4.42 & 3.91 & 4.12 & 3.33 & 2.89 \\
\hline Ea & 0.43 & 0.45 & 0.39 & 0.44 & 1.09 & 1.31 & 2.2 & 1.37 & 1.31 & 1.30 & 1.82 & 156 & 1.43 & 1.12 & 1.00 \\
\hline Gd & 1.82 & 1.96 & 1.33 & 1.54 & 3.28 & 3.47 & 7.01 & 6.01 & 5.88 & 5.65 & 7.96 & 6.91 & 6.06 & 5.42 & 4.54 \\
\hline $\mathrm{Tb}$ & 0.40 & 0.43 & 0.61 & 0.71 & 0.46 & 0.49 & 0.93 & 0.88 & 0.86 & 0.77 & 1.21 & 1.13 & 0.96 & 0.89 & 0.75 \\
\hline Dy & 3.44 & 3.56 & 4.10 & 4.72 & 2.17 & 2.48 & 4.86 & 5.35 & 5.01 & 5.13 & 7.18 & 6.19 & 557 & 5.27 & 4.12 \\
\hline Ho & 0.82 & 0.84 & 1.23 & 1.90 & 0.45 & 0.55 & 0.90 & 1.12 & 1.01 & 0.98 & 1.35 & 1.25 & 1.15 & 1.13 & 0.88 \\
\hline Er & 2.34 & 2.47 & 2.76 & 3.15 & 1.11 & 1.36 & 1.99 & 2.99 & 2.72 & 2.68 & 3.62 & 3.13 & 3.10 & 3.15 & 2.45 \\
\hline $\mathrm{Tm}$ & 0.36 & 0.38 & 0.53 & 0.61 & 0.16 & 0.22 & 0.29 & 0.41 & 0.39 & 0.36 & 0.46 & 0.48 & 0.45 & 0.46 & 0.36 \\
\hline $\mathrm{Yb}$ & 2.47 & 2.63 & 3.14 & 3.60 & 0.78 & 1.18 & 1.56 & 2.59 & 2.45 & 2.31 & 2.85 & 2.80 & 2.69 & 2.81 & 2.16 \\
\hline $\mathrm{La}$ & 0.39 & 0.42 & 0.52 & 0.60 & 0.12 & 0.19 & 0.23 & 0.40 & 0.39 & 0.38 & 0.51 & 0.44 & 0.40 & 0.41 & 0.31 \\
\hline$\Sigma \mathrm{REE}$ & 19.43 & 20.60 & 24.45 & 28.48 & 113.92 & 122.85 & 194.99 & 61.07 & 57.40 & 53.98 & 24.34 & 65.80 & 63.67 & 50.14 & 44.75 \\
\hline $\mathrm{L}=\mathrm{Yb}$ & 0.34 & 0.35 & 0.42 & 0.42 & 22.26 & 15.08 & 15.93 & 1.31 & 1.16 & 1.14 & 1.32 & 1.11 & 1.45 & 0.90 & 1.17 \\
\hline $\mathrm{Eu} / \mathrm{En}^{*}$ & 1.20 & 1.13 & 1.08 & 1.09 & 0.91 & 0.93 & 0.92 & 0.86 & 0.84 & 0.92 & 0.92 & 0.90 & 0.87 & 0.80 & 0.84 \\
\hline
\end{tabular}

${ }^{*} \mathrm{wt} \%$ for major elements, ppm for trace elements.

The Weiya mafic granulites are characterized by high $\mathrm{CaO}(14.2-16.9 \%)$ and $\mathrm{FeO}^{\mathrm{t}}$ $\left(\mathrm{Fe}_{2} \mathrm{O}_{3}+\mathrm{FeO}=9.9-11.3 \%\right)$ and low $\mathrm{Al}_{2} \mathrm{O}_{3}(12.8-14.8 \%)$. The $\mathrm{SiO}_{2}$ contents vary from 47.45 to $50.43 \%$. It is suggested that the protolith of the Weiya mafic granulites should be cpx-rich gabbro or basalt. The Weiya intermediate granulites have higher $\mathrm{SiO}_{2}(60.8-66.5 \%)$ and $\mathrm{Al}_{2} \mathrm{O}_{3}(13.1-15.7 \%)$ contents, similar to the chemical compositions of quartz dioritic rocks. The Yushugou mafic granulites also have similar high $\mathrm{CaO}(13.8-15.2 \%)$ and low $\mathrm{Al}_{2} \mathrm{O}_{3}$ (12.6- 15.8\%) contents, but higher $\mathrm{TiO}_{2}$ and lower $\mathrm{SiO}_{2}$ contents than the Weiya mafic granulites.

The Weiya mafic granulites have very low rare earth element (REE) contents (19.4-28.5 ppm) and their chondrite-normalized data (Anders and Grevesse, 1989) show LREE-depleted patterns without a significant Eu anomaly ( Table 4, Fig. 6a). Their $(\mathrm{La} / \mathrm{Yb})_{n}$ ratios vary from 0.34 to 0.42 , and $\mathrm{Eu} / \mathrm{Eu}^{*}$ from 1.08 to 1.20 . This REE pattern is similar to that of oceanic tholeiite and indicates that the primary basaltic magma might have derived from depleted mantle. In the primitive mantle-normalized spidergrams, however, these granulites exhibit extremely high $\mathrm{Rb}$, Th, $\mathrm{K}$ and $\mathrm{Sr}$ values (Fig. $6 \mathrm{~b}$ ), which are probably related to late stage metasomatism during retrograde metamorphism due to granitoid magmatism. 

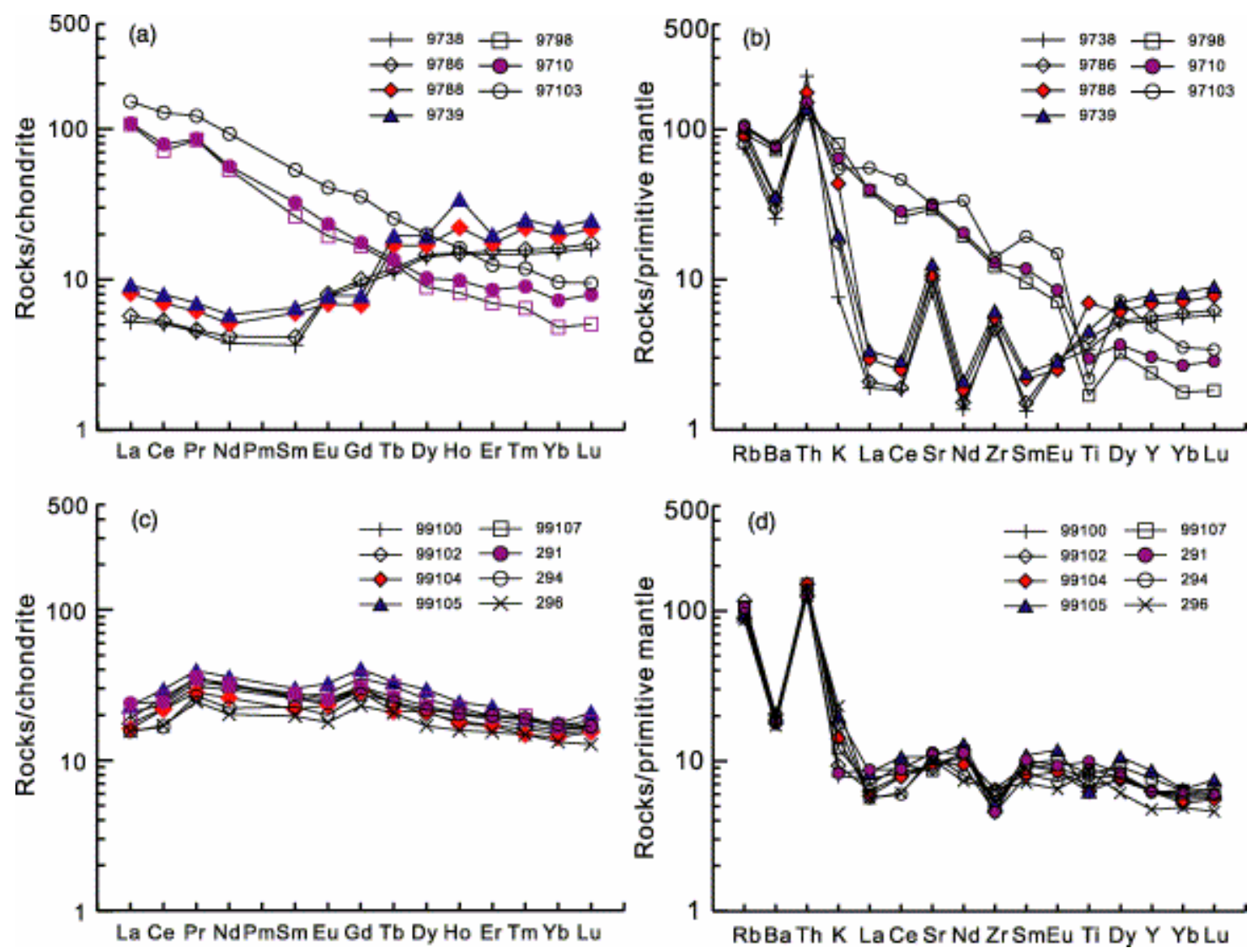

Fig. 6. Chondrite-normalized REE patterns and primitive mantle-normalized incompatible element concentration distribution of granulites from the Weiya and the Yushugou, eastern Tianshan. (a) and (b) The Weiya mafic and intermediate granulites. (c) and (d) The Yushugou mafic granulites. Chondrite value is after Anders and Grevesse (1989) and primitive mantle value is after McDonough and Sun (1995).

The Weiya intermediate granulites have very high REE contents (113.9-194.6 ppm), and display a LREE-enriched pattern with minor Eu anomalies (0.91-0.93) (Table 4, Fig. 6a). All intermediate granulites show minor to medium $\mathrm{Ti}$ depletion, and a marked $\mathrm{Th}$ positive anomaly ( Fig. 6b), which are possibly related to late alteration.

The Yushugou mafic granulites have higher REE contents $(44.7-74.3 \mathrm{ppm})$ than the Weiya mafic granulites. The REE patterns are flat with a little hump at Gd (Fig. 6c). Their $(\mathrm{La} / \mathrm{Yb})_{\mathrm{n}}$ ratios are between 0.90 and 1.45 with a mean value of 1.25 for eight samples. This type of REE pattern is similar to cpx-rich cumulate granulite (Yu et al., 2003), which is consistent with their major element features. Like the Weiya granulites, the Yushugou granulites have high $\mathrm{Rb}$, and Th contents ( Fig. 6d), which might have resulted from late-stage metasomatism.

\subsection{Tectonic setting of the protolith generation of mafic granulites}

Four discrimination diagrams based on Ti, Mn, P, Zr and Y contents (Mullen, 1983; Pearce and Cann, 1973; Pearce and Norry, 1979 and Pearce, 1982) were chosen to constrain the tectonic setting of the protolith of the Weiya and the Yushugou granulites. The minor and trace elements used in these diagrams must be relatively immobile during granulite facies metamorphism and metasomatism (during retrograde metamorphism). In these four discrimination diagrams, all the Weiya and Yushugou mafic granulite data are plotted in the 
fields of island arc tholeiite, or volcanic arc basalt, or MORB+VAB ( Fig. 7). The IAT setting is likely the best candidate. These results indicate that the protolith of eastern Tianshan granulites probably formed in a volcanic island arc tectonic setting.
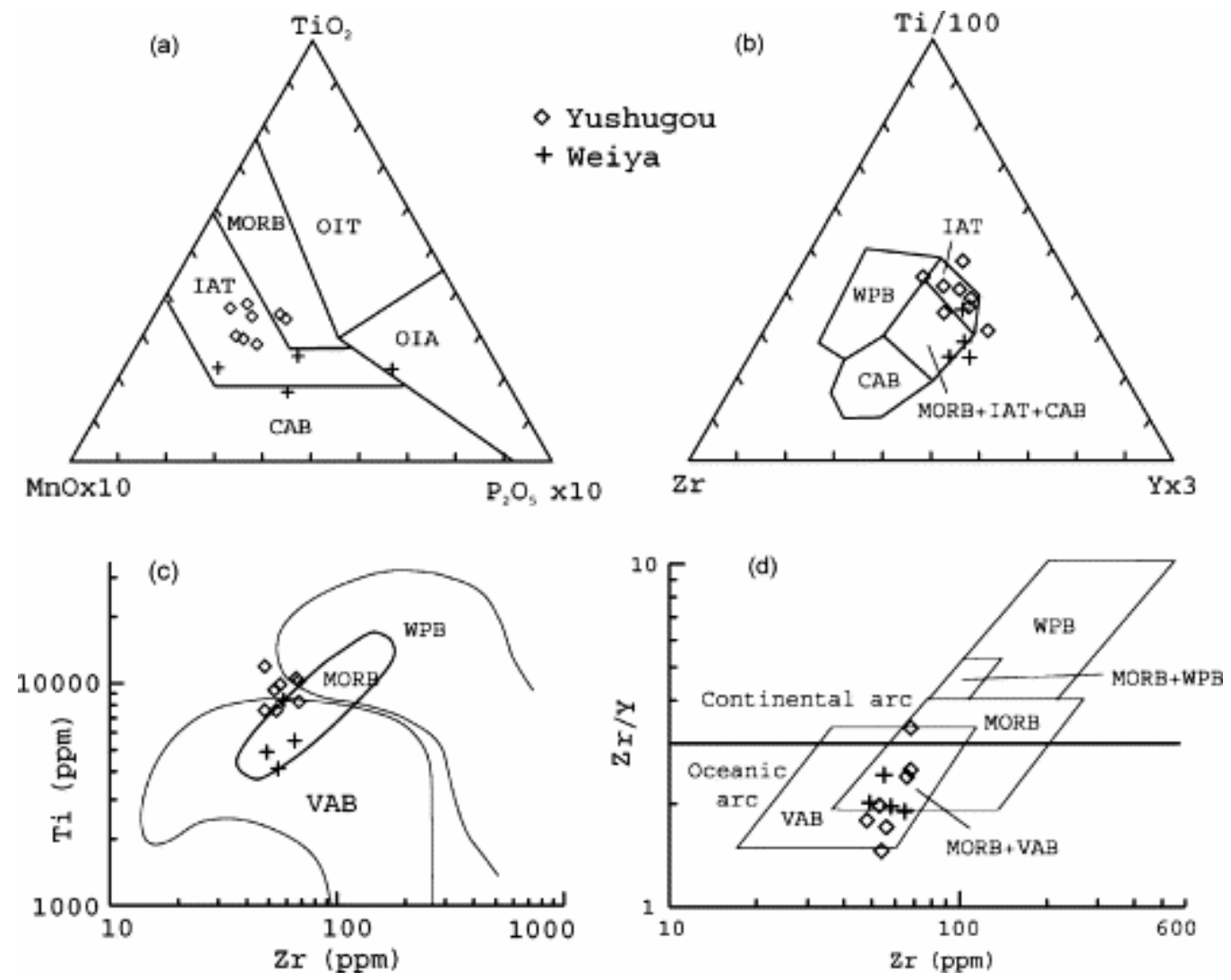

Fig. 7. Discrimination diagrams of tectonic settings for the Weiya and the Yushugou mafic granulites (a) $\mathrm{TiO}_{2}-$ MnO- $\mathrm{P}_{2} \mathrm{O}_{5}$ diagram (after Mullen, 1983); (b) Ti-Zr-Y diagram (after Pearce and Cann, 1973); (c) Ti-Zr variation plot (after Pearce, 1982); (d) Zr/Y-Zr plot (after Pearce and Norry, 1979). MORB, Middle ocean ridge basalt; OIT, Ocean island tholeiite or seamount tholeiite; OIA, Ocean island alkali basalt or seamount alkali basalt; IAT, Island arc tholeiite; CAB, Calc-alkaline basalt; WPB, Within-plate basalt; VAB, Volcanic arc basalt.

\section{Conclusions}

1. Two km-scale ancient granulites were recently reported that are exposed as fault-bounded slabs in the Tianshan belt, mainly in the Weiya area along the northern boundary of the central Tianshan sub-belt and in the Yushugou area along the northern boundary of the southern Tianshan sub-belt.

2. Structural analyses provide evidence of polyphase deformation for these granulites, characterized by ductile shear microstructures of garnet-pyroxene grains and feldspar-quartz grains. Evidence of ductile deformation of the Weiya granulite suggests that a deep-seated garnet-pyroxene prograde metamorphism and shearing occurred in the Tianshan region, and evolved into feldspar-quartz facies retrograde metamorphism and deformation, followed by top-to-the north thrust movement.

3. Rock types of the Weiya granulite include the dark two-pyroxene granulite, garnetclinopyroxene granulite and light clinopyroxene granulite. These rocks show porphyroblastic and fine-grained textures along with banded and massive structures. Their protoliths are basic rocks (cpx-rich gabbro or basalt) and intermediate rocks (quartz diorite or andesite), 
respectively. The Yushugou granulites are distributed as thrust slabs in the allochthonous ophiolitic mélange. Three types of structures have been observed, namely porphyroblastic, banded, and massive structures. Their protoliths are mainly basic rocks (gabbro or basalt).

4. Three stages of metamorphism were recorded in the Weiya granulites: $\mathrm{M}_{1}=\mathrm{Pl}+\mathrm{Qtz}+\mathrm{Bt}$, $\mathrm{M}_{2}=\mathrm{Cpx}+\mathrm{Grt}+\mathrm{Pl}+\mathrm{Qtz}+\mathrm{Atp} \pm \mathrm{Opx}$, and $\mathrm{M}_{3}=\mathrm{Amp}+\mathrm{Ep}+\mathrm{Pl}+\mathrm{Bt}+\mathrm{Qtz}$. They were formed during pre-peak, peak and post-peak metamorphism, respectively. Two stages of metamorphic assemblages were observed in the Yushugou granulites: $\mathrm{M}_{1}=\mathrm{Cpx}+\mathrm{Grt}+\mathrm{Pl} \pm \mathrm{Hyp}$, and $\mathrm{M}_{2}=\mathrm{Amp}+\mathrm{Pl}+\mathrm{Qtz} \pm \mathrm{Bt}$, representing peak- and post-peak metamorphism, respectively. The $T$ $P$ estimation suggests that peak metamorphism of the Weiya granulite took place under the $T$ $P$ conditions of $910-1025$ and $1.08-1.12 \mathrm{GPa}$, associated with retrograde metamorphism at $650-670{ }^{\circ} \mathrm{C}$, and the Yushugou granulite under conditions of $800-870{ }^{\circ} \mathrm{C}$ and $0.88-1.13$ $\mathrm{GPa}$.

5. The Weiya mafic granulites are characterized by high $\mathrm{CaO}, \mathrm{FeO}^{\mathrm{t}}\left(\mathrm{Fe}_{2} \mathrm{O}_{3}+\mathrm{FeO}\right)$ and low $\mathrm{Al}_{2} \mathrm{O}_{3}$, low $\sum \mathrm{REE}$ contents and LREE-depleted REE patterns, indicating that the primary basaltic magma was derived from a depleted mantle. The Weiya intermediate granulites have higher $\mathrm{SiO}_{2}$ and $\mathrm{Al}_{2} \mathrm{O}_{3}$, higher $\sum$ REE contents and LREE-rich REE patterns, similar to that of the quartz dioritic rocks in an island arc setting. The Yushugou mafic granulites also have high $\mathrm{CaO}$ and low $\mathrm{Al}_{2} \mathrm{O}_{3}$ contents, but higher $\mathrm{TiO}_{2}$ and lower $\mathrm{SiO}_{2}$ contents than the Weiya mafic granulites. Their REE patterns are similar to that of cpx-rich cumulate granulite. Geochemical features indicate that the protoliths of the Weiya and the Yushugou mafic granulites probably formed in the island arc tectonic setting, implying that there was a late Precambrian active continental margin in this area.

6. This paper reports the inner $\mathrm{Sm}-\mathrm{Nd}$ isochron age of the Weiya granulite: $538 \pm 24 \mathrm{Ma}$, representing the age of peak metamorphism. This event was possibly related to plate subduction, providing a clue to the latest Precambrian crustal evolution in the study region. The ${ }^{40} \mathrm{Ar} /{ }^{39} \mathrm{Ar}$ dating on amphibole separates from the Weiya granulite yielded a plateau age of $432 \pm 1 \mathrm{Ma}$ for the retrograde metamorphism, which represents a last exhumation event, suggesting significant influence of the early Paleozoic tectonothermal event.

\section{Acknowledgements}

Two reviewers, Dr Shuwen Liu and Dr M.B. Allen, the Editor-in-Chief Kevin Burke and Dr J. Lytwyn are gratefully acknowledged for their constructive comments and many important corrections in English, which greatly improve the manuscript. Prof. Zhu Jinchu, Dr Tan Xiaodong and Prof. Ling Hongfei of Nanjing University (China) are thanked for their checking earnestly over this revised manuscript for English grammar and sentence structures. Dr Chen Xiaoming is thanked for his expert support for electron microprobe analyses. We also thank Guo Zhaojie, Li Jingyi and Gao Jun for their fruitful discussions and valuable suggestions. This research is supported by the National 973 Project of China (Grant No. 2001CB409804) and partly by the Laboratoire de Geologie Structurale of Orleans University, France.

\section{References}

Ai, Y., 1994. A revision of the garnet-clinopyroxene $\mathrm{Fe}^{+2}-\mathrm{Mg}$ exchange geothermometer. Contributions to Mineralogy and Petrology 115, pp. 467-473. 
Allen, M.B., Windley, B.F. and Zhang, C., 1993. Paleozoic collisional tectonics and magmatism of the Chinese Tien Shan, central Asia. Tectonophysics 220, pp. 89-115.

Allen, M.B., Windley, B.F., Zhang, C. and Guo, J.H., 1993. Evolution of the Turfan basin, Chinese Central Asia. Tectonics 12, pp. 889-896.

Allen, M.B., Sengor, A.M.C. and Natal'in, B.A., 1995. Junggar, Turfan, and Alakil basins as Late Permian sinistral pull-apart structures in the Altaid orogenic collage, central Asia. Journal of the Geological Society, London 152, pp. 327-338.

Allen, M.B., Alsop, G.I. and Zhemchuzhnikov, V.G., 2001. Dome and basin refolding and transpressive inversion along the Karatau fault system, southern Kazakstan. Journal of the Geological Society, London 158, pp. 83-95.

Anders, E. and Grevesse, N., 1989. Abundances of He elements: meteoric and solar. Geochimica et Cosmochimica Acta 53, pp. 197-214.

Bohlen, S.R. and Mezger, K., 1989. Origin of granulite terranes and the formation of the lowermost continental crust. Science 244, pp. 326-329.

Burtman, V.S., 1975. Structural geology of the Variscan Tien Shan, USSR. American Journal of Science 275A, pp. 157-186.

Carroll, A.R., Graham, S.A., Hendrix, M.S., Ying, D. and Zhou, D., 1995. Late Paleozoic tectonic amalgamation of NW China: sedimentary records of the northern Tarim. Northwestern Turpan, and southern Juggar basins. Bulletin of Society of America 107, pp. 571-594.

Che, Z., Liu, H. and Liu, L., 1994. The formation and evolution of the central Tianshan orogenic belt, Geological Publishing House, Beijing 135 pp. (in Chinese)

Coleman, R.G., 1989. Continental growth of northwest China. Tectonics 8 3, pp. 621-635. Abstract-INSPEC | Abstract-GEOBASE | Order Document

DePaolo Donald, J., 1988. Neodymium isotope geochemistry: an introduction, Springer, Berlin 187 pp. .

Ellis, D.J., 1987. Origin and evolution of granulites in normal and thickened crust. Geology 15, pp. 167-170.

Gao, J., He, G.Q., Li, M.S., Xiao, X.C., Tang, Y.Q., Wang, J. and Zhao, M., 1995. The mineralogy, petrology, metamorphic PTDt trajectory and exhumation mechanism of blueschist, south Tianshan, northwestern China. Tectonophysics 250, pp. 151-168.

Gao, J., Wang, Z.X., Zhang, L.F. and Shadeke, A., 1997. Formation environment of highpressure metamorphic rocks, West Tianshan, Xinjiang, China. Continental Dynamics 2 1, pp. $12-21$. 
Gao, J., Klemd, R., Zhang, L., Wang, Z.X. and Xiao, X.C., 1999. P-T path of highpressure/low-temperature rocks and tectonic implications in the western Tianshan mountains, NW China. Journal of Metamorphic Geology 17, pp. 621-636.

Gu, L.X., Yang, H. and Tao, X.C., 1990. Rb-Sr Geochronology of granites in the east section of the Mid-Tianshan belt and its tectonic evolution. Journal of Guilin College of Geology 10 1, pp. 50-54 (in Chinese with English abstract).

$\mathrm{Gu}, \mathrm{L} ., \mathrm{Hu}, \mathrm{S}$. and $\mathrm{Chu}, \mathrm{Q} ., 1999$. Pre-collision granites and post-collision intrusive assemblage of the Kelameili-Harlik orogenic belt. Acta Geological Sinica 73 3, pp. 316-329.

Guo, J., Shu, L., Charvet, J., Laurent-Charvet, S. and Sun, S., 2002. Geochemical features of the two early Paleozoic ophiolitic zones and the volcanic rocks in the Central-Southern Tianshan region, Xinjiang. Chinese Journal of Geochemistry 21 4, pp. 308-321.

Guo, Z., Xie, Y. and Ma, J., 1999. Ultra-microscopic image features of gabbro mylonites and their original dynamic environment in the Xinjiang-Ganshu frontier. Earth Sciences 24 4, pp. 383-386 (in Chinese with English abstract).

He, G., Li, M., Liu, D. and Zhou, N., 1994. Paleozoic crustal evolution and mineralization in Xinjiang of China, Xinjiang People's Publishing House, Urumqi 437 pp. (in Chinese with English abstract).

Hoisch, T.D., 1989. A muscovite-biotite geothermometer. American Mineral 74, pp. 565-572.

Hopson, C., Wen, J., Tilton, G., Tang, Y., Zhu, B. and Zhao, M., 1989. Palaeozoic plutonism in East Junggar, Bogdashan, and eastern Tianshan, NW China. EOS, Transaction on American Geophysics Union 70, pp. 1403-1404.

$\mathrm{Hu}$ Aiqin, Zhang Guoxin, 1995. Study on geological features of Precambrian basement and foresee of ore deposits in the northern Xinjiang orogenic belt, China. Unpublished dissertation of the Xinjiang Bureau of National 305 Project, Urumqi, 215 pp. (in Chinese).

Laurent-Charvet, S., Charvet, J., Shu, L., Ma, R. and Lu, H., 2002. Palaeozoic late collisional strike-slip deformations in Tianshan and Altay, Eastern Xinjiang, NW China. Terra Nova 14 4, pp. 249-256.

Liu, S., 1997. Study of fluid-rock equilibrium systems of Fuping gneiss complex, Taihang Mountains. Science in China (Series D) 40 3, pp. 239-245.

Liu, S., Liang, H.H., Zhao, G.C., Hua, Y.G. and Jian, A.H., 2000. Isotopic chronology and geological events of Precambrian complex in Taihangshan region. Science in China (Series D) 43, pp. 386-393.

Liu, S., Pan, Y., Li, J., Li, Q. and Zhang, J., 2002. Geological and isotopic geochemical constraints on the evolution of the Fuping Complex, North China Craton. Precambrian Research 117, pp. 47-56. 
Ma, R., Wang, C. and Ye, S., 1993. The outline of plate tectonics and crustal evolution in the eastern Tianshan belt, China, Publishing House of Nanjing University, Nanjing 225 pp. (in Chinese) .

Ma, R., Shu, L. and Sun, J., 1997. Tectonic evolution and metallization in the Eastern Tianshan belt, China Geological Publishing House, Beijing 202 pp. (in Chinese with detailed English abstract) .

McDougall, I. and Harrison, M., 1988. Geochronology and thermochronology by the ${ }^{40} \mathrm{Ar}{ }^{39} \mathrm{Ar}$ method, Clarendon Press, Oxford $212 \mathrm{pp}$.

McDonough, W.F. and Sun, S.S., 1995. The composition of the earth. Chemical Geology 120, pp. 223-253.

Menzies, M.A., 1992. The lower lithosphere as a major source for continental flood basalts: a re-appraisal (P). In: Storey, B.C., Alabaster, T. and Pankhurst, R.J., Editors, 1992. Magmatism and Causes of Continental Break-up vol. 68, Geological Society Special Publisher, pp. 31-39.

Monie, P., Torres-Roldan, R.L. and Garcia-Casco, A., 1994. Cooling and exhumation of the Western Betic Cordilleras, ${ }^{40} \mathrm{Ar} /{ }^{39} \mathrm{Ar}$ thermochronological constraints on a collapsed terrane. Tectonophysics 238, pp. 353-379.

Mullen, E.D., 1983. $\mathrm{MnO} / \mathrm{TiO}_{2} / \mathrm{P}_{2} \mathrm{O}_{5}$ : a minor element discriminant for basaltic rocks of oceanic environments and its implications for petrogenesis. Earth Planet Science Letters 62, pp. 53-62.

Nakajima, T., Maruyama, S., Uchiumi, S., Liou, J.G., Wang, X.M., Xiao, X.C. and Graham, S.A., 1990. Evidence for late Proterozoic subduction from 700-Myr-old blueschist in China. Nature 346, pp. 263-265.

Newton, R.C. and Perkins, D., 1982. The thermodynamic calibration of geobarometers based on the assemblage garnet-plagioclase-orthopyroxene (clinopyroxene)-quartz. American Mineral 67, pp. 203-222.

Nickel, H.G. and Green, D.H., 1985. Empirical geothermobarometry for garnet peridotites and implications for the nature of the lithosphere, kimberlites and diamonds. Earth Planet Science Letters 73, pp. 158-170.

Pearce, J.A., 1982. Trace element characteristics of lavas from destructive plate boundaries. In: Thorpe, R.S., Editor, 1982. Andesites, Wiley, Chichester pp. 525-548 .

Pearce, J.A. and Cann, J.R., 1973. Tectonic setting of basic volcanic rocks determined using trace element analyses. Earth Planet Science Letters 19, pp. 290-300.

Pearce, J.A. and Norry, M.J., 1979. Petrogenetic implications of Ti, Zr, Y and $\mathrm{Nb}$ variations in volcanic rocks. Contributions to Mineralogy and Petrology 69, pp. 33-47.

Ravna, E.K., 2000. the garnet-clinopyroxene $\mathrm{Fe}^{+2}-\mathrm{Mg}$ geothermometer: an updated calibration. Journal Metamorphic Geology 18, pp. 211-219. 
Ren, J.S. and Chen, T., 1989. Tectonic evolution of the continental lithosphere in eastern China and adjacent areas. J. Southeast Asian Earth Science 3, pp. 17-27.

Sengor, A.M.C., Natal'in, B.A. and Burtman, B., 1993. Evolution of the Altaid tectonic collage and Paleozoic crustal growth in Eurasia. Nature 364, pp. 299-307.

Shu, L., Wang, C. and Ma, R., 1996. Granulite relics and pyroxene-facies ductile deformation in the northern boundary of the southern Tianshan. Scientia Geologica Sinica 31 4, pp. 63-71 (in Chinese with English abstract) .

Shu, L., Ma, R. and Wang, C., 1997. Research on the thrust tectonics of the Eastern Tianshan belt, Xinjiang. Scientia Geologica Sinica 32 3, pp. 337-350 (in Chinese with English abstract)

Shu, L., Charvet, J., Guo, L. and Lu, H., 1999. A large-scale Paleozoic dextral ductile strikeslip zone: the Aqqikkudug-Weiya zone along the northern margin of the Central Tianshan belt, Xinjiang, NW China. Acta Geologica Sinica 73 2, pp. 148-162.

Shu, L., Chen, Y., Lu, H., Charvet, J., Laurent-Charvet, S. and Yin, D., 2000. Paleozoic accretionary terranes in Northern Tianshan, NW China. Journal of Chinese Geochemistry 19 3, pp. 193-202.

Shu, L., Charvet, J., Lu, H. and Laurent-Charvet, S., 2002. Paleozoic accretion-collision events and kinematics of ductile deformation in the central-southern Tianshan Belt. China Acta Geologica Sinica 76 3, pp. 308-323.

Wang, R., Zhou, D., Wang, J. and Wang, Y., 1999. A study of Variscan deep crustal granulite terrane in the Yushugou, Eastern Tianshan. Science in China (Series D) 29 4, pp. 306-313.

Wartes, M.A., Carroll, A.R. and Greene, T.J., 2002. Permian sedimentary record of the Turpan-Hami basin and adjacent regions, Northwest China: Constrains on postamalgamation tectonic evelution. Geological Society of American Bulletin 114 2, pp. 131-152.

Wells, P.R.A., 1977. Pyroxene thermometry in simple and complex system. Contributions to Mineralogy and Petrology 62, pp. 129-139.

Whitney, J.A. and Stormer Jr., J.C., 1977. The distribution of $\mathrm{NaAlSi}_{3} \mathrm{O}_{8}$ between coexisting microcline and plagioclase and its effect on geothermometric calculations. American Mineral 62, pp. 687-691.

Windley, B.F., Allen, M.B., Zhang, C., Zhao, Z.Y. and Wang, G.R., 1990. Paleozoic accretion and Cenozoic redeformation of the Chinese Tienshan range. Central Asian Geology 18, pp. 128-131. Abstract-INSPEC | Order Document

Wood, B.J. and Banno, S., 1973. Garnet-orthopyroxene and orthopyroxene-clinopyroxene relationships in simple and complex systems. Contributions to Mineralogy and Petrology 42, pp. 109-124. 
XBGMR: Xinjiang Bureau of Geology and Mineral Resources, 1992. Geological map of Xinjiang Uygur Autonomy Region, Geological Publishing House, Beijing four sheets, scale $1: 1500000$.

XBGMR: Xinjiang Bureau of Geology and Mineral Resources, 1993. Regional geology of Xinjiang Uygur Autonomy Region, Geological Publishing House, Beijing 841 pp. (in Chinese with English abstract) .

Xiao, X.C., Tang, Y.Q., Li, J.Y., Zhao, M., Feng, Y.M. and Zhu, B.Q., 1990. On the tectonic evolution of the northern Xinjiang, Northwest China. Geoscience of Xinjiang 1, pp. 47-68 (in Chinese with English abstract) .

Xu, Z., 1995. Large shear zones in the main orogenic belts of China. Episodes 18 1-2, pp. 4143.

Yu, J., Xu, X., O'Reilly, S.Y., Griffin, W.L. and Zhang, M., 2003. Granulite xenoliths from Cenozoic basalts in SE China provide geochemical fingerprints to distinguish lower crust terranes from the North and South tectonic blocks. Lithos. 67, pp. 77-102. 